\title{
Metformin alters signaling induced crosstalk and homeostasis in the carcinogenesis paradigm "Epistemology of the origin of cancer"
}

\author{
Björn L.D.M. Brücher ${ }^{1,2,3, *}$ and Ijaz S. Jamall ${ }^{1,2,4}$ \\ ${ }^{1}$ Theodor-Billroth-Akademie ${ }^{\circledR}$, Germany, USA \\ ${ }^{2}$ INCORE, International Consortium of Research Excellence of the Theodor-Billroth-Academy ${ }^{\circledR}$, Germany, USA \\ ${ }^{3}$ Department of Surgery, Carl-Thiem-Klinikum, Cottbus, Germany \\ ${ }^{4}$ Risk-Based Decisions Inc., Sacramento, CA, USA
}

Received 27 March 2018, Accepted 4 March 2019

\begin{abstract}
The anti-hyperglycemic drug, Metformin, is effective in treating early stages of diabetes and has been associated with a $37 \%$ decrease in cancer incidence. While the precise mechanisms for the anti-cancer effects of Metformin remain to be elucidated, this review shows the multiplicity of its effects on interdicting signaling and crosstalk, anti-inflammatory effects and in restoring homeostasis, which, taken together, go beyond its well-known anti-hyperglycemic effect that serves as the basis for its use in type 2 diabetes. Metformin is much more than a one-trick pony. The recent discovery of several signaling pathways influenced by Metformin appears to have potential value in cancer therapy. Based on what we know at present, Metformin promotes beneficial effects attributed to its anti-inflammatory and anti-fibrotic effects largely demonstrated in vitro. Metformin activates or upregulates while it simultaneously inhibits or downregulates multiple signaling pathways of cell-cycle arrest and apoptosis accompanied by oxidative stress, which are in accordance with the 6-step sequence of carcinogenesis. Furthermore, in vivo studies in laboratory animals and in cancer patients are beginning to address the magnitude of the anti-cancer effects and delineate its anti-cancer effects. In this context, results from prior pancreatic and non-pancreatic cancer trials, which contained a significant proportion of the patient population treated with Metformin, will have to be reexamined in light of the observed anticancerous effects to gain additional insights. The detailed exploration of Metformin in the context of the "Disruption of signaling homeostasis induced crosstalk in the carcinogenesis paradigm Epistemology of the origin of cancer" can provide helpful insights into the anti-proliferative mechanisms and could play a relevant role in anti-cancer therapy in the future.
\end{abstract}

Keywords: Akt, ALL, ALK-1, AMP, AMPK, Apoptosis, Autophagy, Bax, Bcl-2, BrDU, Breast cadherin, Cancer, Carcinogenesis, Cell transition, Chronic inflammation, Collagen, Collagenase, Colon, CCC, Cox-1, Cox-2, CRP, CXCL8, Decorin, Diabetes, DNA, EGFR, Elastin, Elastase, Endometrium, Epidemiology, Epigenetics, Erk, Fibronectin, Fibrosis, FOXO3a, Genetics, Genomics, GRIM-19, GTPase, HCC, HER2/neu, HIF-1 $\alpha$, HPV, Interleukin, Keratin, Keratinase, KRAS; liver, LOX, MAPK, MCP1, Metastasis, Metformin, Microbiome, microRNA, MMP, mTOR, mTORC1, Mutation, NF- $\kappa$ B, NLRP3, NRF-2, NSCLC, Ovary, PAI-1, PARP, Pathogenesis, PCK, PEPCK, PGE2, PPA2, Precancerous niche, Proteomics, Pyroptosis, RNA, Signaling, Snail, Somatic mutation theory, STAT3, T2D, TGF, TIMP1, Vimentin, Virus

\section{Introduction}

An exploration of the potential ant-cancer effects of Metformin must necessarily begin with an understanding of type 2 diabetes (T2D) and the epidemic of obesity, the latter also a recognized risk factor in several cancers. The proportion of people above 60 years old will increase from 841 million at present to an estimated 2 billion by 2050 according to the World Health Organization [1]. This will increase the burden of age-related chronic diseases such as

*Corresponding author: b-bruecher@gmx.de cancer, neurologic and cardiovascular diseases and T2D as the global costs for healthcare worldwide [2]. The increase in metabolic syndrome, defined by three out of five medical conditions, which include obesity, elevated blood pressure, insulin resistance, elevated fasting plasma glucose, high serum triglycerides, and low levels of high-density cholesterol (HDL), is a risk factor for T2D [3] and explains the parallel increase of T2D prevalence in the US [4], Asia [5], Europe [6], and the Middle East [7] reflecting global healthcare liabilities. T2D is associated with morbid obesity and some $35 \%$ (78.6 million) of US adults are obese [8]. 
Recently, an increase of gestational diabetes from $7.4 \%$ to $14.1 \%$ within the US over an 11 year period was reported [9]. An estimated $40 \%$ of the US population is at risk of developing $\mathrm{T} 2 \mathrm{D}$, and the corresponding percentage in Blacks or Hispanics within the US is thought to be as high as $50 \%$ [10]. A $10 \%$ increase in the prevalence of $\mathrm{T} 2 \mathrm{D}$ in patients between 40 and 74 years of age in individuals with a body mass index $(\mathrm{BMI}) \geq 30 \mathrm{~kg} / \mathrm{m}^{2}$ was reported [11]. "In high-income countries, reduction in non-tobacco cardiovascular disease and diabetes mortality contributed most to gains in life expectancy at age 60 years between 1980 and 2011" [12] but the trend of growth in morbid obesity with its developing T2D may can counteract or reverse this effect within the future.

A European scenario, based on current and past BMI trends, revealed that morbid obesity is expected to increase in 53 European countries through 2030 with the highest prevalence in Greece, the United Kingdom, and Slovakia [6].

The interaction of the microbiome and morbid obesity in relation to cancer is reviewed elsewhere in this special issue [13]. Increased cancer rates associated with diabetes are reported for breast cancer, colorectal cancer, liver and pancreatic cancers, bladder cancer, and endometrial cancer [14], while the risk of developing prostate cancer is paradoxically decreased $[15,16]$.

Understanding the interaction of the microbiome with morbid obesity in the context of signaling and crosstalk together with the apparent beneficial effects of Metformin will enhance our understanding of carcinogenesis and of the effectiveness of Metformin in cancer therapy.

\section{Metformin}

Metformin is a biguanid (1,1-Dimethylbiguanid) used in the management of T2D (National Institute of Health) [17]. The exact mechanism of action of Metformin is not fully understood. Over the past decade, Metformin has been shown to reduce cancer risk by about 37\% [18]. The incidence of intrahepatic cholangiocellular carcinoma (CCC) was reduced by about $60 \%$ in Metformin-treated T2D patients [19].

In a rat model, it was shown that Metformin blocks testosterone which also explains why Metformin might be useful in treating polycystic ovarian syndrome (PCOS) [20-22]. However, at present PCOS is an off-label use for Metformin [23].

A study using patient-derived xenograft (PDX) lines from two colorectal cancer patients for assessing Metformin and 5-fluorouracil (5-FU) showed that Metformin inhibited tumor growth by at least $50 \%$ after 24 days and, when combined with 5 -FU, tumor growth was inhibited by as much as $85 \%$ [24]. Metformin can reduce the growth of mammary cancer cells in mice, which also shows its anti-metabolic effects [25]. The experiment showed that modulated microRNA contributes to both the metabolic as well as the anticancer effects of Metformin. In this connection, Metformin results in increased expression of Dicer, an endoribonuclease responsible for cutting double-stranded ribonucleic acid (RNA) into shorter double-stranded fragments. When Dicer was eliminated in knock-out mice, these effects were suppressed. Metformin also downregulates messenger RNAs (mRNAs) such as c-MYC, insulin-receptor substrate 2 (IRS-2) and hypoxia-inducible factor-1 alpha (HIF-1 $\alpha$ ). The regulation of $\mathrm{c}-\mathrm{MYC}$ requires adenosine monophosphate (AMP) signaling and the upregulation of the microRNA (miRNA) precursor, miR33 [26].

\section{Metformin and microbiome}

Metformin influences the composition of the intestinal flora by increasing anaerobic gram-negative bacteria, Akkermansia, and mucin-producing goblet cells [27]. Otherwise, the Metformin-microbiota interactions are varied: Houttuynia cordata extract (HCE) together with Metformin influences the composition of the gut microbiota by decreasing Gram-negative bacteria [28]. Metformin can increase and trigger the abundance of opportunistic pathogens with dysbiosis [29] and thus Metformin can induce changes in signaling as well as inducing altered microbiota signatures [30-37]. Typically diet and fat metabolism influences the microbiome composition [38-41].

Genes for fatty acid metabolism of triglycerides, HDL, and insulin pathways are regulated by miR33 [42]. miR33 binds to the tumor suppressor gene, p53, resulting in activation of apoptosis [43]. Metformin downregulates miR-21 through the transforming growth factor beta 1 (TGF- $\beta 1$ ) pathway such that overexpression of miR-21 abrogates Metformin-mediated inhibition of the protein kinase B (PKB, Akt), SMAD, and extracellular signal-regulated kinases (ERKs) signaling pathways and can abolish the inhibitory effects of Metformin-induced protein phosphorylation [44].

Activin receptor-like kinase 1 (ALK-1) signaling inhibits lymphatic vessel formation [45] and mediates angiogenesis in solid tumors, which serves as a basis for using it as a target in cancer therapy [46, 47]. Metformin also activates AMP activated protein kinase (AMPK), inhibiting ALK-1 mediated angiogenesis [48, 49] but it appears that Metformin has a short-term paradoxical effect by increasing pro-angiogenic mediators [50]. This needs further study for clarification.

\section{Metformin and apoptosis}

Metformin is known to induce apoptosis [51-53] but can block methylglyoxal (MG)-induced apoptosis in neuronal cells [54]. In pancreatic cancer cells, Metformin induces apoptosis in a dose-dependent manner through activation of caspase-3, -8, and -9 and poly-ADP-ribose polymerase (PARP) cleavage [55]. Furthermore, Metformin induces apoptosis in lung [56] and colon cancers [57, 58].

Metformin was shown to induce the inflammatory form of apoptosis, pyroptosis, in esophageal squamous cell carcinoma (ESCC) via proline-, glutamic acid- and leucine-rich protein-1 (PELP1) and miR-497 [59]. Apoptosis is also inhibited by Metformin in melanoma [60]. On the other hand, Metformin has been reported to decrease chemotherapy induced apoptosis [61]. However, this effect seems to be 
dependent on whether or not hypoxic conditions are present as Metformin was shown to be limited in its ability to activate AMPK and inhibit mTOR signaling in hypoxic pediatric sarcomas [62]. Typically, large tumors have a higher rate of central hypoxic conditions [63, 64], and the Metformin effect could be dependent on the hypoxic and/ or central necrotic areas within the tumor.

Scientists from Brazil and Canada investigated the molecular mechanisms for the observed anti-cancer effects of Metformin by assessing its ability to induce apoptosis and cell cycle arrest [65]. Metformin was administered at 24,48 , and $72 \mathrm{~h}$ in vitro in an established breast cancer cell line (MCF-7, American Type Culture Collection, Middlesex, United Kingdom). The controls used a carcinoma cell line and rats (LLC WRC-256 Walker rats). Bromo-deoxyuridine (=bromo-2'-deoxyuridine, BrDU) as the pyrimidine analog of thymidine can be selectively incorporated into deoxyribonucleic acid (DNA) during the S-phase of the cell cycle so that BrDU can be used for the identification of DNA-synthesis in cells, smears, and tissue probes. Specific monoclonal antibodies against BrDU allow assessment of DNA-synthesis and of cell kinetics and cell proliferation. Metformin decreased the activation of insulin receptor $\beta$ (IR $\beta)$, Akt, and extracellular signal-regulated kinase 1 (Erk1, mitogen-activated protein kinase 3, MAPK3)/extracellular signal-regulated kinase 2 (Erk2, mitogen-activated protein kinase 1, MAPK1) in mice followed by increased phosphorylated AMPK (pAMPK), forkhead box O3 (FOXO3a), cyclin-dependent kinase inhibitor 1B (p27), B-cell lymphoma 2 (Bcl-2)-associated X protein (Bax) and cleaved caspase-3. This was associated with decreased phosphorylation of ribosomal protein $\mathrm{S} 6$ kinase beta-1 (p70S6 K) and B-cell lymphoma 2 protein (Bcl-2) expression with consequent increase of phosphorylated p38 mitogen-activated protein kinases (MAPKs), catalase, manganese-dependent superoxide dismutase (MnSOD, SOD2) and superoxide dismutase 1 (SOD1, Cu-Zn SOD) protein expression, and an anti-proliferative effect by inducing apoptosis and cell cycle arrest mediated via AMPK and FOXO3a. Furthermore, Metformin increases carcinoma cell apoptosis and senescence in stromal cells [66].

\section{Metformin and inflammation}

The significance of chronic inflammation in carcinogenesis has been reviewed [67]. In addition, an anti-inflammatory effect of Metformin was shown through the reduction of C-reactive protein (CRP), a marker of inflammation [68]. In human ovarian SKOV3 and HO-8910PM cell lines, Metformin inhibited proliferation and adhesion in a dosedependent manner and decreased cancer cell growth and metastasis in vivo [69], along with the plasminogen activator inhibitor-1 (PAI-1) [70].

A randomized, placebo-controlled trial with T2D patients treated with insulin plus either Metformin or placebo showed that the addition of Metformin resulted in a reduction of von Willebrand factor ( $\mathrm{vWF})$, soluble vascular adhesion molecule-1 (sVCAM-1), tissue-type plasminogen activator (t-PA), PAI-1, CRP, and soluble intercellular adhesion molecule-1 (sICAM-1) [71]. Typically, Metformin triggers AMPK-endothelial nitric oxide (NO) synthase (eNOS)-mediated signaling which has cardioprotective effects and a $34 \%$ decrease in cardiovascular morbidity and mortality in patients with myocardial infarction [72].

Recently, the anti-inflammatory effects of Metformin were further elaborated. Interleukin 8 (IL-8, C-X-C motif ligand (CXCL) 8, CXCL8) is increased in certain cancers such as stomach [73], breast [74, 75], pancreas [76], prostate [77], and colon [78] and these cancers are known to recruit inflammasome cells such as neutrophil granulocytes, monocytes and leukocytes [79]. Using the HEK293/TLR4 cell line, Metformin administration decreased the cell migration by "lipopolysaccharide (LPS) induced CXCL8 expression in a dose-dependent manner through inhibiting nuclear factor kappa-light-chain-enhancer of activated $B$ cells $(N F-\kappa B) "[80]$.

\section{Metformin and fibrosis with its remodeling - precancerous niche (PCN)}

The signaling and crosstalk of remodeled fibrosis by chronic inflammation and its induction of a precancerous niche $(\mathrm{PCN})$ has been reviewed [81]. Metformin protects against radiation-induced pneumonitis and fibrosis $[82,83]$ which was reported in liver cells and found to be associated with the mechanistic target of rapamycin (mTOR)/HIF- $1 \alpha$ inhibition [84].

Thrombospondin-1 (TSP-1) is increased by Metformin via $\mathrm{NF}-\kappa \mathrm{B}$ and Erk1/2/extracellular signal-regulated kinase 5 (Erk5, mitogen-activated protein kinase 7, MAPK7) pathways and thus decreases angiogenesis [85]. Metformin decreases hypoxia-induced angiogenesis by decreasing HIF- $1 \alpha$ and angiogenesis-associated factors (AAFs) [86, 87].

Metformin downregulates the structural proteins $\operatorname{Col} 3 \alpha$, Col $6 \alpha$, elastin and the collagen cross-linking enzyme, lysyl oxidase (LOX), tumor necrosis factor alpha (TNF $\alpha$ ), IL-6, monocyte chemoattractant protein 1 (MCP1, chemokine (C-C motif) ligand 2, CCL2) and epidermal growth factor (EGF)-like module-containing mucin-like hormone receptor-like 1 (EMR1, F4/80) which is an indicator of macrophages recruitment, and also inhibits HIF- $1 \alpha$ activation-induced fibrosis and inflammation in adipose tissue [88]. Metformin abrogates receptor tyrosine-protein kinase erbB-2 (HER2/neu, cluster of differentiation 340, CD340) signaling-induced tumor angiogenesis by inhibiting VEGF secretion and reduces micro-vessel density [89-92].

Metformin suppresses the inhibitor of nuclear factor kappa-B kinase subunit beta (IKK $\beta$, inhibitor of nuclear factor kappa-B kinase 2, IKK2) and also inhibits chemokine (C-X-C motif) ligand 1 (CXCL1) [93], downregulates chemokine (C-X-C motif) ligand 10 (CXCL10), tissue inhibitor of metalloproteinase 1 (TIMP1) [94], and inhibits PAI-1 [70]. As Metformin inhibits PAI-1, it also inhibits the creation of the PCN and thereby can affect the transition of a normal cell to a cancer cell. As TIMP-1 promotes liver metastasis [95], this pathway might also be interdicted by Metformin. 


\section{Metformin: leptin, STAT3, and adenosine monophosphate (AMP) activated protein kinase (AMPK)}

Metformin increases leptin sensitivity in rats fed a high fat diet which suggests that Metformin could be effective in treating obesity [96]. Metformin treatment resulted into an increase of transcription factor signal transducer and activator of transcriptor 3 (STAT3). However, intracerebroventricular leptin investigations of anorexic and fatlosing effects showed that lower leptin doses were required to induce these effects in Metformin-treated high-fat fed obese rats than in untreated rats, suggesting that anorexic and fat-losing effects of leptin were enhanced by Metformin. Leptin decreased hypothalamic pAMPK levels, which were not observed by Metformin treatment. Intracerebroventricular injections of Metformin in another animal model decreased food intake with an increase of cyclic AMPK (cAMPK) and STAT3 but increasing the Metformin dosage did not have an effect on a further pAMPK or STAT3 increases leading to the inference that Metformin may be helpful in the treatment of mild-to-moderate obesity [97]. These effects of Metformin are relevant as obesity is a risk factor for several cancers [13].

Hepatic gluconeogenesis is inhibited by Metformin through the activation (phosphorylation) of AMPK [98, 99]. Recently, this mechanism was revised to include that Metformin antagonizes glucagon through AMP accumulation in mouse hepatocytes where it inhibits adenylate cyclase with suppression of a glucagon-induced increase of cyclic adenosine-monophosphate (cAMP) with protein kinase A (PKA). These effects result in the inhibition of glucagon-dependent glucose output from hepatocytes with a corresponding decrease in blood glucose [98, 100]. Furthermore, the inhibition of gluconeogenesis by suppression of the mitochondrial glycerophosphate-dehydrogenases has been elucidated [101].

Transgenic mice treated with Metformin showed an increase of AMPK activity with inhibition of mTOR [102]. Metformin inhibits hepatic mammalian target of rapamycin complex 1 (mechanistic target of rapamycin complex 1, mTORC1) signaling by dose-dependent mechanisms through adipocyte AMPK and the tuberous sclerosis complex (TSC) [103] but this inhibition also occurs via an AMPK-independent pathway [104, 105]. This pathway may also be triggered by Ragulator-Rag complex (RAG) guanosine triphosphate hydrolase (GTPase) independently from TSC/mTOR/AMPK [106]. Inhibition of the mTOR effector, p70S6K1, was associated with a decrease in human HER2/neu inhibiting breast carcinoma cell growth ([107 reviewed in 108]).

In contrast to the obese animal model discussed above [96, 97], Metformin inhibits cell transition and metastasis by decreasing cyclooxygenase-2 (Cox-2)/prostaglandin E2 (PGE2)/STAT3 signaling in prostate cancer cells [109]. Here, inactivating Cox-2 abolished Metformin effects while PGE2 administration increased STAT3 and cell transition. The combined treatment with Metformin and aspirin in liver cancer HepG2 cells downregulated pAMPK and
mTOR with consecutive induction of apoptosis and G2/ $\mathrm{M}$ cell arrest. Investigation of hepatocellular carcinoma (HCC) specimens showed increased pAMPK, mTOR and $\beta$-catenin compared to cirrhotic liver tissue controls [110]. Furthermore, Metformin sensitized sorafenib therapy suppressing cell proliferation and transition with promoting apoptosis presumably by decreasing insulin resistance [111]. In cancer stem cells, the Metformin effect was dependent on AMPK-mTOR and glutamine metabolism [112].

The human enzyme phosphoenolpyruvate carboxykinase (PEPCK, PCK) has a cytoplasmic (PCK1, PEPCKC) and mitochondrial isoform (PCK2, PEPCK-M); PCK is a key enzyme for (1) gluconeogenesis, (2) glyceroneogenesis, (3) serine synthesis and (4) conversion of the carbon skeletons of amino acids. PCK converts oxaloacetate into phosphoenolpyruvate and carbon dioxide and serves as a cataplerotic enzyme resulting into anabolic metabolism ([113-115 reviewed in 116]). Corticoids and cAMP increase, while insulin negatively regulates PCK [117]. However, over $80 \%$ of tumors and $78 \%$ of non-tumor tissue express PCK1 while investigations using colon cancer cell lines revealed an overexpression by $\sim 17 \%$ [118] and mitochondrial PCK2 was overexpressed in thyroid, bladder, breast, kidney, and non-small-cell lung cancer (NSCLC) [119]. In contrast, PCK1 and PCK2 are downregulated in HCC, rarely mutated in HCC, and forced PCK1 expression suppresses liver cancer growth in HCC [120, 121]. PCK1 activates pAMPK with suppression of cell proliferation and growth, and Metformin as an AMPK activator suppresses HCC growth [122].

Furthermore, another dysregulation of homeostasis is found in HCC: $11 \beta$-hydroxysteroid dehydrogenase type 1 $(11 \beta$-HSD1) is downregulated while $11 \beta$-HSD2 is upregulated which can be reversed by dexamethasone [120] and here Metformin shows yet another effect by increasing $11 \beta$-HSD1 in morbid obesity [123].

In a study of sugar uptake, Onodera et al. [124] demonstrated that overexpression of glucose transporter type 3 (GLUT3) in non-malignant human breast cells activated known oncogenic signaling pathways including epidermal growth factor receptor (EGFR), $\beta 1$ integrin, mitogenactivated protein kinase kinase 2 (MAPK2, MEK), and Akt, leading to a loss of tissue polarity and increased growth. Conversely, reduction of glucose uptake in malignant cells facilitated the formation of normal cell growth with basal polarity and suppressed oncogenic pathways. Loss of epithelial integrity involved activation of Ras-related protein 1 (Rap1, Ras-proximate-1) via exchange protein directly activated by cAMP - exchange factor directly activated by cAMP 1 , exchange factor directly activated by cAMP 1 (EPAC1, Rap guanine nucleotide exchange factor 3, RAPGEF3) -, involving O-linked N-acetylglucosamine modification downstream of the hexosamine biosynthetic pathway, mediated by pyruvate kinase M2 (PKM2) and soluble adenylyl cyclase (sAC), respectively. The authors state, "Unexpectedly and importantly, we found that unlike reported literature, in $3 D$ the differences between "normal" and malignant phenotypes could not be explained by HIF-1 $\alpha, A M P K$ or mTOR pathways." The extent to which 
Metformin might directly affect these specific pathways is not well understood but these studies illustrate the importance of $2 \mathrm{D}$ versus $3 \mathrm{D}$ cell assays and suggest targets for future studies.

Metformin in Porphyromonas gingivalis (P.g.)-infected streptozotocin (STZ)-induced diabetic mice was shown to suppress the inflammasome by inhibiting NIMA-related kinase 7(Nek7)/NOD-like receptor family pyrin domain containing 3 (NLRP3) expression independently of mTOR [125].

\section{Metformin and cell transition}

Cell transition during carcinogenesis is complex [126]. The observed inhibition of cell-cell transition by Metformin likely works through multiple pathways. Metformin is an activator of AMPK and also suppresses cell transition via inhibition of reactive oxygen species (ROS) mediated by induction of heme oxygenase- 1 and the endogenous antioxidant, thioredoxin [127]. Metformin was shown to inhibit cell transition in prostate cancer cells by inhibiting TGF- $\beta$, $\mathrm{N}$-cadherin, vimentin and epithelial Cadherin (E-cadherin, cadherin-1, CAM 120/80) and $\beta$-catenin at mRNA and protein levels [128]. This may also be associated with upregulation of miR30a and downregulation of the [sexdetermining region $\mathrm{Y}$ (Sry) box-containing] transcription factor 4 (SOX4).

Metformin inhibits TGF- $\beta 1$-induced cell transition via pyruvate kinase M2 (PKM2) relative-mTOR and p70s6 k signaling [129]. On the one hand, high glucose itself induces downregulation of the mitochondrial gene associated with retinoid-IFN-induced mortality 19 (GRIM-19, NADH dehydrogenase [ubiquinone] 1 alpha subcomplex subunit 13, NDUFA13) with activation of STAT3 signaling resulting in cell proliferation [130]. In this regard, Metformin did not have an effect on phosphorylated STAT3 levels in the HeLa cells, but decreased STAT3 levels in myoblast $\mathrm{H} 9 \mathrm{C} 2$ cells.

Metformin inhibits IL-6-induced cell transition which may be related to the blocking of STAT3 phosphorylation [131]. Metformin also inhibits the nuclear translocation of NF- $\kappa$ B and phosphorylation of STAT3 [132] and the Janus kinase (JAK), STAT3, c-MYC signaling axis [133-135]. By downregulating STAT3, Metformin promotes autophagy [136] as discussed earlier [67]. Knockdown of TGF- $\beta 1$ plus Metformin in a canine mammary cancer xenograft model decreased cell transition and metastasis (cell line, CF41) [137].

Metformin application to the human AGS gastric cancer cell line showed decrease of vimentin, $\beta$-catenin, and induction of E-cadherin [138]. Using a human cholangiocarcinoma cell line, HuCCT1, plus Metformin, showed downregulation of the anti-apoptotic protein, Bcl-2, and induced myeloid leukemia cell differentiation protein (Mcl-1), cadherin-2 (N-cadherin, neural cadherin), zinc finger protein SNAI1 (Snail), and matrix metalloproteinase-2 (MMP-2, gelatinase A) as well as decreased STAT3 activation together with increased of E-cadherin expression [139].
It was also demonstrated earlier that Metformin increases E-Cadherin while decreasing matrix metalloproteinase-9 (MMP-9, gelatinase B)) expression [140].

Metformin downregulates/decreases IR $\beta$, Akt, IKK $\beta$, CXCL1, CXCL10, TIMP1, vWF, PAI-1, mTORC1 signaling by dose-dependent mechanisms through adipocyte AMP-activated protein kinase (AMPK) and the TSC Complex, NF- $\kappa \mathrm{B}$, CRP, miR-21 through the TGF- $\beta$ pathway, c-MYC, IRS-2, HIF-1 $\alpha$, Col $3 \alpha$, Col $6 \alpha$, Elastin, LOX, TNF- $\alpha$, IL- 6 , MCP1, TGF- $\beta 1$ via PKM2 relativemTOR/p70s6 k signaling, Cox-2/PGE2/STAT3 signaling, STAT3 and its phosphorylation, EMR1, microvessel density, JAK/STAT3/c-MYC pathway, vimentin, $\beta$-catenin, Bcl-2, Mcl-1, N-cadherin, Snail, MMP-2, MMP-9, and ROS via induction of heme oxygenase- 1 and endogenous antioxidant thioredoxin (Fig. 1). Otherwise Metformin upregulates/activates E-cadherin, Dicer, sVCAM-1, t-PA, sICAM-1, p-AMPK, FOXO3a, p70S6 K, and IL-8 (expression in a dose-dependent manner through inhibiting NF- $\kappa \mathrm{B}$ ), and increases TSP-1 via NF- $\kappa \mathrm{B}$ and Erk1/2/ Erk5.

\section{Metformin and clinical trials}

Searching the US National Library of Medicine from the National Institute of Health (NIH) on Feb 20, 2019 for the variables "metformin" and "cancer" and "trial", yielded $n=315$ documented trials independent from its active status or various entities [141].

The detailed signaling and crosstalk resulting from a pathogenic stimulus and which evokes the chronic inflammation involved in morbid obesity had been reviewed earlier (reviewed in $[13,67]$ ). This is of significance in neurological diseases such as Parkinson or dementia as well (reviewed in [142]). Metformin is increasingly becoming recognized for decreasing the inflammasome. Recently, a matched-pair retrospective cohort trial in 15,676 individuals from Taiwan investigated the dementia risk in T2D and Metformin: "The overall hazard ratios suggested a significantly lower risk of dementia associated with metformin use in either the unmatched cohort or the matched cohort. In tertile analyses, the hazard ratios suggested a reduced risk in a dose-response pattern" [143].

In 2005, a case-control study from Tayside in Scotland evaluated $314,127 \mathrm{~T} 2 \mathrm{D}$ patients and selected 11,876 who were newly diagnosed with diabetes. From this pool, 923 patients who had been admitted to a hospital with a cancer diagnosis were selected [144]. Two randomized control cases were selected for each Metformin case and were matched for age, year of diagnosis, and gender. The study concluded that the administration of Metformin reduced cancer risk in T2D patients, including in patients with breast [145], prostate [146] and colon cancers [98].

In a study of 123 acute lymphoblastic leukemia (ALL) patients treated with and without Metformin, the overall survival at a median follow up of 700 days of follow-up was $43 \%$, with a disease-free survival of $47 \%$. Patients with Metformin had a lower rate of relapse compared to the 


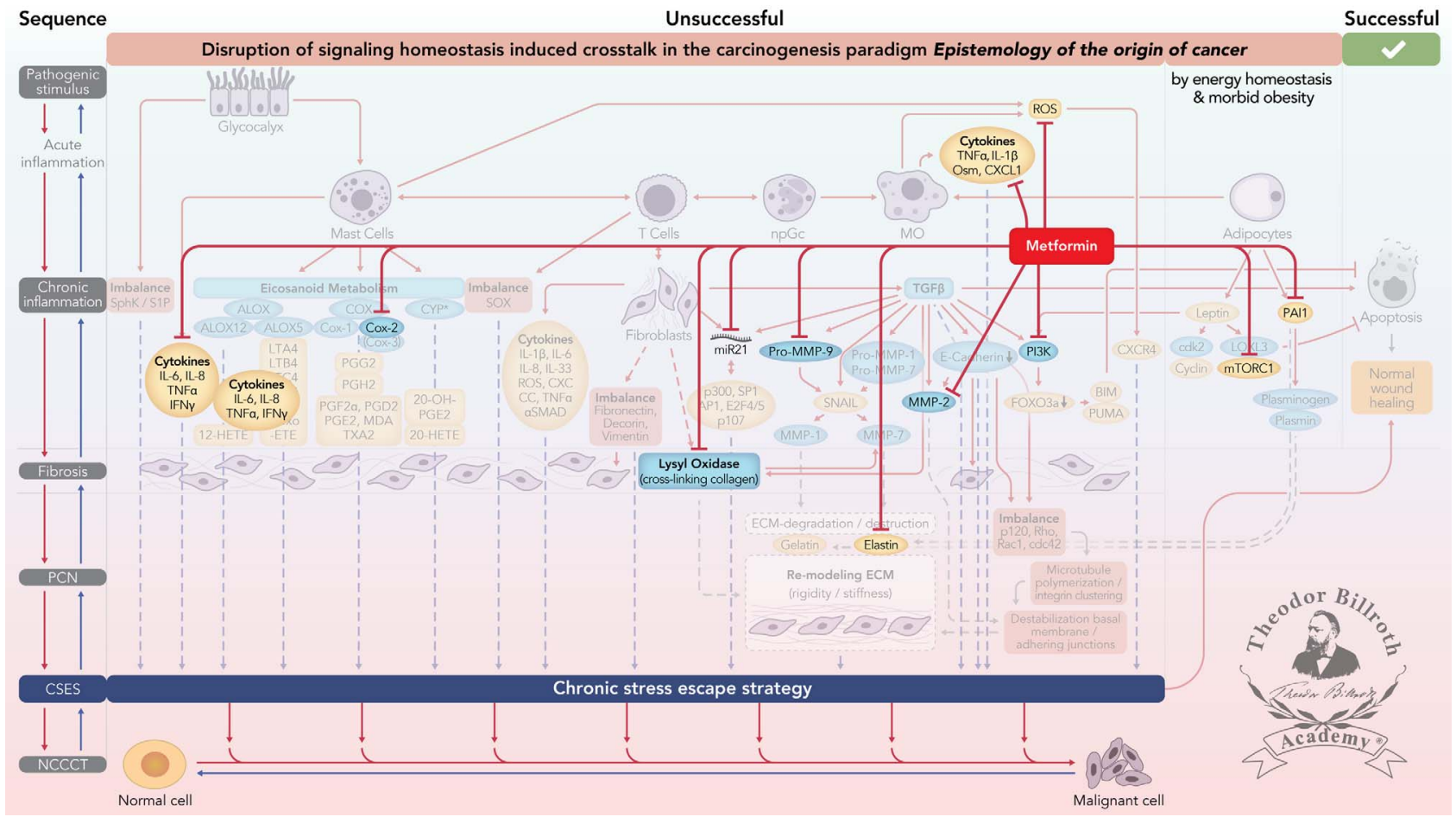

Figure 1. Metformin alters signaling induced crosstalk and homeostasis in the carcinogenesis paradigm "Epistemology of the origin of cancer" modified in accordance to Figure 1 published in this special issue [67]. Simplified scheme of the disruption of signaling homeostasis-induced crosstalk in the carcinogenesis paradigm "epistemology of the origin of cancer" consisting of a six-step sequence: (1) a pathogenic stimulus followed by (2) chronic inflammation from which develops (3) fibrosis with associated remodeling of the cellular microenvironment; and from these changes a (4) precancerous niche (PCN), a product of fibrosis, with remodeling by persistent inflammation, develops that triggers the deployment of (5) a chronic stress escape strategy and when this fails resolve it by (6) normal cell to cancerous cell transition (NCCCT) by PCN-induced cell matrix stress [67]. This figure was published as original illustration in paper 3 of this Special Issue - Disruption of homeostasis-induced signaling and crosstalk in the carcinogenesis paradigm "Epistemology of the origin of cancer" entitled "Chronic inflammation evoked by pathogenic stimulus during carcinogenesis". We point out, that to the complexity of the content of the Special Issue the original and/or modified version of the original illustration was republished within the following papers of the Special Issue: paper 5 "Microbiome and morbid obesity increase pathogenic stimulus diversity", paper 6 "Precancerous niche (PCN), a product of fibrosis with remodeling by incessant chronic inflammation", paper 7 "Metformin alters signaling homeostasis", paper 8 "Transition from normal to cancerous cell by precancerous niche (PCN) induced chronic cell-matrix stress" and paper 9 "NF- $\kappa$ B signaling and crosstalk during carcinogenesis". Nomenclature: Common abbreviations are bold, followed by the common trivial names (if available) and (if available) by the name in accordance to the International Union of Pure and Applied Chemistry (IUPAC): PCN: precancerous niche; CSES: chronic stress escape strategy; NCCCT: normal cell to cancerous cell transition; SphK: sphingosine kinase isoform; S1P: sphingosine-1-phosphate; IL-6: interleukin 6; IL-8: interleukin 8; TNF $\alpha$ : tumor necrosis factor alpha; IFN $\gamma$ : interferon gamma; ALOX: lipoxygenase, arachidonate lipoxygenase; ALOX12: 12-lipoxygenase, 12-LOX, 12S-LOX, arachidonate 12-lipoxygenase 12S type; ALOX5: 5- lipoxygenase, 5-LOX, arachidonate 5-lipoxygenase; 12-HETE: 12-hydroxyeicosatetraenoic acid; LTA4: leukotriene A4, 4-[(2S,3S)-3-[(1E,3E,5Z,8Z)-tetradeca-1,3,5,8-tetraenyl]oxiran-2-yl] butanoic acid; LTB4: leukotriene B4, (5S,6Z,8E,10E,12R,14Z)-5,12-dihydroxyicosa-6,8,10,14-tetraenoic acid; LTC4: leukotriene C4, (5S,6R,7E,9E,11Z,14Z)-6-[(2R)-2-[[(4S)-4-amino-4-carboxybutanoyl]amino]-3-(carboxymethylamino)-3-oxopropyl]sulfanyl-5-hydroxyicosa-7,9,11,14-tetraenoic acid; LTD4: leukotriene D4, (5S,6R,7E,9E,11Z,14Z)-6-[(2R)-2-amino-3-(carboxymethylamino)3-oxopropyl]sulfanyl-5-hydroxyicosa-7,9,11,14-tetraenoic acid; LTE4: leukotriene E4, (5S,6R,7E,9E,11Z,14Z)-6-[(2R)-2-amino2-carboxyethyl]sulfanyl-5-hydroxyicosa-7,9,11,14-tetraenoic acid; 5-oxo-ETE: (6E,8Z,11Z,14Z)-5-oxoicosa-6,8,11,14-tetraenoic acid; Cox: cyclooxygenase; Cox-1: cyclooxygenase 1; Cox-2: cyclooxygenase 2; Cox-3: isoform of Cox-2 (therefore in brakes); PGG2: prostaglandin G2, (Z)-7-[(1S,4R,5R,6R)-5-[(E,3S)-3-hydroperoxyoct-1-enyl]-2,3-dioxabicyclo[2.2.1]heptan-6-yl]hept-5-enoic acid; PGH2: prostaglandin H2, (Z)-7-[(1S,4R,5R,6R)-5-[(E,3S)-3-hydroxyoct-1-enyl]-2,3-dioxabicyclo[2.2.1]heptan-6-yl]hept-5-enoic acid; PGFF2 $\alpha$ : prostaglandine F2 alpha, (Z)-7-[(1R,2R,3R,5S)-3,5-dihydroxy-2-[(E,3S)-3-hydroxyoct-1-enyl]cyclopentyl]hept-5-enoic acid; PGD2: prostaglandin D2, (Z)-7-[(1R,2R,5S)-5-hydroxy-2-[(E,3S)-3-hydroxyoct-1-enyl]-3-oxocyclopentyl]hept-5-enoic acid; PGE2: prostaglandin E2, (Z)-7-[(1R,2R,3R)-3-hydroxy-2-[(E,3S)-3-hydroxyoct-1-enyl]-5-oxocyclopentyl]hept-5-enoic acid; MDA: malondialdehyde, propanedial; TXA2: thromboxane A2, (Z)-7-[(1S,2S,3R,5S)-3-[(E,3S)-3-hydroxyoct-1-enyl]-4,6-dioxabicyclo[3.1.1]heptan2-yl]hept-5-enoic acid; CYP*: cytochrome P450 isoforms; 20-OH-PGE2: 20-hydroxy prostaglandin E2; 20-HETE: 20-hydroxyeicosatetraenoic acid, (5Z,8Z,11Z,14Z)-20-hydroxyicosa-5,8,11,14-tetraenoic acid; SOX: [sex-determining region Y (Sry) box-containing] transcription factor family; IL- $\beta$ 1: interleukin beta 1 ; IL-33: interleukin 33 ; ROS: reactive oxygen species; CXC CC: chemokine receptors; $\alpha$ SMAD: alpha-smooth muscle actin; miR21: micro RNA-21; p300: protein 300 (p300-CBP coactivator family); SP1: specificity protein 1; AP1: activator protein 1; E2F4/5: cytoplasmic complex of Smad3, retinoblastoma-like protein 1 (P107, RBL1), E2F4/5 and D-prostanoid (DP1); p107: retinoblastoma-like protein 1, RBL1; TGF $\beta$ : transforming growth factor beta; Pro-MMP-9: pro-matrix metalloproteinase 9; Pro-MMP-1: pro-matrix metalloproteinase 1; Pro-MMP-7: pro matrix 
group receiving only chemotherapy $(6.5 \%$ vs. $17.1 \%$, $P=0.006)$. The addition of metformin to the conventional treatment of ALL was associated with an improvement in survival, this association being independent of the type of biological risk at diagnosis [147].

Adding Metformin to simvastatin in PCOS increased therapeutic efficacy from $66.7 \%$ to $92.6 \%$. In this study, efficacy was defined $>15 \%$ decrease in the baseline values with regard to ovarian size, luteinizing hormone/folliclestimulating hormone $(\mathrm{LH} / \mathrm{FSH})$ ratio, and lipid profile [148]. In an in vitro study using HT29 colon cancer cells, treatment with different concentrations of Metformin demonstrated growth inhibitory effects by increasing both apoptosis and autophagy; moreover, Metformin affected the survival of cultured cells by inhibiting the transcriptional activation of nuclear factor (erythroid-derived)-like 2 (NRF-2, NFE2L2) and NF- $\kappa$ B. Importantly, the effects were dose- and time-dependent. These results are very intriguing since Metformin is emerging as a multi-faceted drug with a good safety profile and low cost and might be a promising candidate for the prevention or the treatment of colorectal cancer [58, 149].

In a recent study (The METTEN study) to assess the efficacy of adding Metformin to neoadjuvant chemotherapy plus trastuzumab in early HER2/neu-positive breast cancer (BC). Women with primary, non-metastatic HER2/ neu-positive $\mathrm{BC}$ were randomized (1:1) to receive Metformin (850 mg twice-daily) for 24 weeks concurrently with 12 cycles of weekly paclitaxel plus trastuzumab, followed by four cycles of 3-weekly FE75C plus trastuzumab (arm A), or equivalent regimen without Metformin ( $\operatorname{arm} \mathrm{B})$, followed by surgery. Primary endpoint was the rate of pathological complete response (pCR) in the per-protocol efficacy population. The $\mathrm{pCR}$ rate was numerically higher in the Metformincontaining arm A (19 of 29 patients [65.5\%, 95\% CI 47.3-80.1]) than in arm B (17 of 29 patients $[58.6 \%, 95 \%$ CI 40.7-74.5]; OR 1.34 [95\% CI 0.46-3.89], $P=0.589$ ). The rate of breast-conserving surgery was $79.3 \%$ and $58.6 \%$ in arm A and B $(P=0.089)$, respectively [150].

In a study of 101 women to assess whether Metformin prevented tamoxifen-induced endometrial changes and insulin resistance (IR) after a diagnosis of breast cancer, Metformin inhibited tamoxifen-induced endometrial changes and had favorable metabolic effects [151]. Application of $1500 \mathrm{mg}$ metformin in a neoadjuvant setting revealed decreased insulin receptor (IR)-mediated and phosphatidylinositide 3-kinase (PI3 K) and Ras-MAPK signaling with less phosphorylation of Akt, Erk1/2 and acetyl coenzyme A carboxylase (ACC) [152].

In patients with endometrial cancer, Metformin was given preoperatively and reduced the serine/threonine phosphatase protein phosphatase 2A (PP2A) by immunohistochemistry and mRNA expression of the PP2A regulatory subunit, serine/threonine-protein phosphatase 2A regulatory subunit B (PPP2R4) measured by RT-PCR. Insulin resistance and diabetes are associated with PP2A [153, 154]. Knockdown of PPA2 in drosophila resulted in increased apoptosis [155] and abolished Erk negative regulating effects [156]. Inhibition of PPA2 by the microbial toxin okadaic acid (OA) activated p53 in T51B rat liver epithelial cells [157] and PP2A holoenzymes activated Akt and Erk signaling [158]. PPA2 and cyclin-Dependent Kinase 5 (CDK5) are independent prognostic factor in patients with gastric cancer [159]. Inhibiting PPA2 through the small molecule phosphatase inhibitor, LB-100, plus anti- programmed cell death protein 1(aPD-1) blockade activates mTORC1 signaling pathway [160]. The PP2A regulatory subunit, PPP2R4, decreases cell proliferation and activates caspases $3 / 7$ increasing apoptosis in the human endometrial cancer cell lines HEC265 and HEC1B. Administering Metformin preoperatively in endometrial cancer patients reduces PP2A [161].

Anticancer effects were demonstrated by adding metformin in the therapy regimen in a small study of 25 patients with advanced or metastatic NSCLC: Metformin together with paclitaxel/carboplatin/bevacizumab improved progression free survival (PFS) by up to $47 \%$ compared to $15 \%$ in controls without improving median survival [162].

Furthermore, Metformin produced pro-apoptotic effects and enhanced the effectiveness of cisplatin specifically in KRAS/liver kinase B1 (LKB1, serine/threonine kinase 11, STK11) co-mutated patient-derived xenografts. Metformin also prevented the development of acquired tumor resistance to five consecutive cycles of cisplatin treatment (75\% response rate with metformin + cisplatin as compared to $0 \%$ response rate with cisplatin), while reducing the number of CD133+ cells [163].

In a retrospective cohort of 87,344 patients with advanced prostate cancer, Cox proportional hazard analysis of overall survival showed improved survival in men with diabetes mellitus on Metformin (HR 0.82, 95\% CI 0.78-0.86) compared to those with diabetes mellitus who were not on Metformin (HR 1.03, 95\% CI 0.99-1.08). Hazard analysis of cancer-specific survival showed improved survival in men with diabetes mellitus on Metformin (HR $0.70,95 \%$ CI $0.64-0.77)$ vs those with diabetes mellitus without Metformin (HR 0.93, 95\% CI 0.85-1.00). The reference group was men with no diabetes mellitus [164].

In a small study of head and neck squamous cell carcinomas (HNSCC), Metformin was shown to differentially impact HNSCC subtypes with greater apoptosis in human papilloma virus negative (HPV-) HNSCC compared to

Figure 1. (Continued) metalloproteinase 7; SNAIL: zinc finger protein SNAI1; MMP-1: matrix metalloproteinase 1; MMP-7: matrix metalloproteinase 7; MMP-2: matrix metalloproteinase 2; E-Cadherin: CAM 120/80 or epithelial cadherin, cadherin-1, epithelial cadherin; CXCL1: chemokine (C-X-C motif) ligand 1; Osm: oncostatin-M; PI3K: phosphatidylinositide 3-kinase; FOXO3a: forkhead box protein O3a; p120: catenin delta-1, protein 120; Rho: Ras homolog gene family, member A; Rac1: Rasrelated C3 botulinum toxin substrate 1; cdc42: cell division control protein 42 homolog; BIM: Bcl-2 interacting mediator of cell death; PUMA: BH3-only protein; CXCR4: C-X-C motif of chemokine receptor 4; cdk2: cyclin-dependent kinase 2; LOXL3: lysyl oxidase homolog 3; mTORc1: rapamycin complex 1; PAI1: Plasminogen activator inhibitor-1. 
human papilloma virus positive $(\mathrm{HPV}+)$ oropharyngeal squamous cell carcinoma. Moreover, the study presented the first in vivo human evidence that Metformin also triggers increased CD8 + Teff and FoxP3 + Tregs in the tumor microenvironment, suggesting an immunomodulatory effect in HNSCC [165]. In a double-blind, randomized, placebo controlled, multicenter study design, metformin in a daily dosage of 2,000 $\mathrm{mg}$ in Barrett's esophagus reduced serum levels of insulin and insulin resistance but were not associated with decrease of a biomarker of insulin pathway activation, phosphorylated S6 kinase (pS6K1), or alter epithelial proliferation or apoptosis in esophageal tissues [166].

\section{Summary}

The anti-hyperglycemic drug, Metformin, is effective in treating early stages of diabetes and is associated with a $37 \%$ decrease in cancer incidence. Several recent clinical studies show the benefits of Metformin as an adjuvant in anti-cancer therapy regimens. Metformin is much more than a one-trick pony. The recent discovery of several signaling pathways influenced by Metformin appears to be of potential value in cancer therapy. Based on what we know at present, Metformin promotes its ant-cancer effects in part due to its anti-inflammatory and anti-fibrotic effects demonstrated in vitro. The biguanid activates or upregulates while simultaneously inhibits or downregulates multiple signaling pathways involved in cell-cycle arrest and apoptosis which are accompanied by oxidative stress. The overall clinical and experimental data for the anti-cancer effects of Metformin are in accordance with the 6-step sequence of carcinogenesis. Further in vivo studies in laboratory animals and in cancer patients will address the magnitude of the anti-cancer effects of this widely used drug and delineate its anti-cancer effects with a long history of safety and low cost. In this context, results from prior pancreatic and non-pancreatic cancer trials which contain a significant proportion of the patient population treated with Metformin should be reexamined to tease out information of anti-cancer effects. Earlier results of applied anticancer therapies may have been masked within a subpopulation of patients who also received Metformin. The detailed exploration of Metformin in the context of the "Disruption of signaling homeostasis induced crosstalk in the carcinogenesis paradigm Epistemology of the origin of cancer" on the one hand can provide significant insights into the anti-proliferative mechanisms and could play a relevant role in anti-cancer therapy in the future.

\begin{tabular}{|c|c|}
\hline \multicolumn{2}{|c|}{ Nomenclature of abbreviations } \\
\hline $5-\mathrm{FU}$ & 5-fluorouracil \\
\hline 5-oxo-ETE & $\begin{array}{l}(6 \mathrm{E}, 8 \mathrm{Z}, 11 \mathrm{Z}, 14 \mathrm{Z})-5 \text {-oxoicosa- } 6,8,11,14 \text {-tet- } \\
\text { raenoic acid }\end{array}$ \\
\hline $11 \beta-\mathrm{H}$ & $\begin{array}{l}11 \beta \text {-hydroxysteroid dehydrogenase } \\
\text { type } 1\end{array}$ \\
\hline
\end{tabular}

12-HETE

20-HETE

20-OH-PGE2

$\alpha$ SMAD

AAFs

ACC

Akt

ALL

ALK-1

ALOX

ALOX5

ALOX12

AMP

AMPK

AP1

Bax

BC

Bcl-2

BIM

BMI

BrDU

cAMP

cAMPK

CCC

CCL2

CD340

cdc 42

cdk2

CDK5

Cox

Cox-1

Cox-2

Cox-3

CRP

CSES

CXC CC

CXCL1

CXCL10

CXCR 4

DNA

E2F $4 / 5$

E-cadherin 12-hydroxyeicosatetraenoic acid 20-hydroxyeicosatetraenoic acid, (5Z,8Z,11Z,14Z)-20-hydroxyicosa$5,8,11,14$-tetraenoic acid

20-hydroxy prostaglandin E2 alpha-smooth muscle actin angiogenesis-associated factors acetyl coenzyme A carboxylase protein kinase B (PKB) acute lymphoblastic leukemia activin receptor-like kinase 1 lipoxygenase, arachidonate lipoxygenase 5- lipoxygenase, 5-LOX, arachidonate 5-lipoxygenase

12-lipoxygenase, 12-LOX, 12S-LOX, arachidonate 12-lipoxygenase $12 \mathrm{~S}$ type adenosine monophosphate adenosine monophosphate (AMP) activated protein kinase

activator protein 1

B-cell lymphoma 2 (Bcl-2)-associated $\mathrm{X}$ protein

breast cancer

B-cell lymphoma 2 protein

B-cell lymphoma 2 protein (Bcl-2)

interacting mediator of cell death

body mass index

bromo-2'-deoxyuridine

cyclic adenosine-monophosphate

cyclic adenosine monophosphate (AMP) activated protein kinase

cholangiocellular carcinoma

chemokine (C-C motif) ligand 2, monocyte chemoattractant protein $1, \mathrm{MCP} 1$

cluster of differentiation 340, receptor tyrosine-protein kinase erbB-2, HER2/neu cell division control protein 42 homolog cyclin-dependent kinase 2

cyclin-dependent kinase 5

cyclooxygenase

cyclooxygenase 1

cyclooxygenase 2

isoform of Cox-2 (therefore in brakes)

C-reactive protein

chronic stress escape strategy

chemokine receptors

chemokine (C-X-C motif) ligand 1

chemokine (C-X-C motif) ligand 10

$\mathrm{C}-\mathrm{X}-\mathrm{C}$ motif of chemokine receptor 4

deoxyribonucleic acid

cytoplasmic complex of Smad3,

retinoblastoma-like protein 1 (P107, RBL1), E2F4/5 and D-prostanoid (DP1)

CAM 120/80 or epithelial cadherin, cadherin-1, 


\section{EMR1}

eNOS

EGFR

EPAC1

ERK

Erk1

Erk2

Erk5

ESCC

FOXO3a

GLUT3

GTPase

GRIM-19

HCC

HCE

HDL

HER2/neu

HIF- $1 \alpha$

HNSCC

HPV

IFN $\gamma$

IKK2

IKK- $\beta$

IL- $\beta 1$

IL-6

IL-8

IL-33

IR $\beta$

IRS-2

JAK

LB-100

LH/FSH

LOX

LOXL3

LKB1 epidermal growth factor (EGF)-like module-containing mucin-like hormone

LPS

LTA4

receptor-like $1, \mathrm{~F} 4 / 80$

endothelial nitric oxide (NO) synthase

epidermal growth factor receptor

LTB4

exchange factor directly activated by

cAMP 1, Rap guanine nucleotide

exchange factor 3, RAPGEF3

extracellular signal-regulated kinase

extracellular signal-regulated kinase 1,

mitogen-activated protein kinase 3 ,

MAPK3

extracellular signal-regulated kinase 2,

mitogen-activated protein kinase 1 ,

MAPK1

extracellular signal-regulated kinase 5, mitogen-activated protein kinase 7 ,

MAPK7

esophageal squamous cell carcinoma

forkhead box protein O3a

glucose transporter type 3

guanosine triphosphate hydrolase

retinoid-IFN-induced mortality $19, \mathrm{NADH}$

dehydrogenase [ubiquinone] 1 alpha

subcomplex subunit 13, NDUFA13

hepatocellular carcinoma

Houttuynia cordata extract

high-density cholesterol

receptor tyrosine-protein kinase erbB-2,

cluster of differentiation 340, CD340

hypoxia-inducible factor-1 alpha

head and neck squamous cell cancer

human papilloma virus

interferon gamma

inhibitor of nuclear factor kappa-B

kinase 2 , inhibitor of nuclear factor

kappa-B kinase subunit beta (IKK- $\beta$ )

inhibitor of nuclear factor kappa-B kinase

subunit beta, inhibitor of nuclear factor

kappa-B kinase 2, IKK2

interleukin beta 1

interleukin 6

interleukin 8 (chemokine (C-X-C motif)

ligand CXCL 8, CXCL8)

interleukin 33

insulin receptor $\beta$

insulin-receptor substrate 2

Janus kinase

small molecule phosphatase inhibitor

luteinizing hormone/follicle-stimulating

hormone

lysyl oxidase

lysyl oxidase homolog 3

liver kinase B1, serine/threonine kinase 11, STK11
LTD4

LTE4

MAPKs

MAPK1

MAPK2

MAPK3

MAPK7

Mcl-1

MCP1

MDA

MG

miRNA

$\operatorname{miR} 21$

MMP-1

MMP-2

MMP-7

MMP-9

MnSOD

mTOR

mTORC1

$\mathrm{N}$-cadherin

NCCCT

Nek7

$\mathrm{NF}-\kappa \mathrm{B}$

NIH

NLRP3

NRF2

NSCLC

$\mathrm{OA}$ lipopolysaccharide

leukotriene A4, 4-[(2S,3S)-3-

[(1E,3E, 5Z,8Z)-tetradeca-1,3,5,8-

tetraenyl oxiran-2-yl|butanoic acid

leukotriene B4, (5S,6Z,8E,10E,12R,14Z)-

5,12-dihydroxyicosa-6,8,10,14-tetraenoic acid

leukotriene C4, (5S,6R,7E,9E,11Z,14Z)-

6-[(2R)-2-[[(4S)-4-amino-4-

carboxybutanoyl]amino]-3-

(carboxymethylamino)-3-oxopropyl]

sulfanyl-5-hydroxyicosa-7,9,11,14-

tetraenoic acid

leukotriene D4, (5S,6R,7E,9E,11Z,14Z)-6-

[(2R)-2-amino-3-(carboxymethylamino)-

3-oxopropyl]sulfanyl-5-hydroxyicosa-

7,9,11,14-tetraenoic acid

leukotriene E4, (5S,6R,7E,9E,11Z,14Z)-6-

[(2R)-2-amino-2-carboxyethyl]sulfanyl-5-

hydroxyicosa-7,9,11,14-tetraenoic acid

p38 mitogen-activated protein kinases

mitogen-activated protein kinase 1 , extracellular signal-regulated kinase 2, Erk2 mitogen-activated protein kinase 2

mitogen-activated protein kinase 3 , extracellular signal-regulated kinase 1, Erk1

mitogen-activated protein kinase 7, extracellular signal-regulated kinase 5, Erk5

induced myeloid leukemia cell differentiation protein

monocyte chemoattractant protein 1 ,

chemokine (C-C motif) ligand 2, CCL2

malondialdehyde, propanedial

methylglyoxal

microRNA

micro RNA-21

matrix metalloproteinase 1

matrix metalloproteinase 2 (gelatinase A)

matrix metalloproteinase 7

matrix metalloproteinase 9 (gelatinase B)

manganese-dependent superoxide

dismutase, SOD2

mechanistic target of rapamycin

mechanistic target of rapamycin complex 1

neural cadherin, Cadherin-2

normal cell to cancerous cell transition

NIMA-related kinase 7

nuclear factor kappa-light-chain-enhancer

of activated B cells

National Institute of Health

NOD-like receptor family pyrin domain containing 3

nuclear factor (erythroid-derived)-like 2, NFE2L2

non-small cell lung cancer

okadaic acid 
Osm

p27

p53

p70S6K

p107

p120

p300

pAMPK

PAI-1

PARP

PCK

PCK1

PCK2

PCN

PCOS

pCR

PD-1

PDX

PELP1

PEPCK

PEPK-C

PEPK-M

PFS

PGG2

PGE2

PGH2

PGFF $2 \alpha$

PGD2

PGE2

PI3K

PKA

PKB

PKM2

PP2A
oncostatin-M

protein 27 , cyclin-dependent kinase

inhibitor $1 \mathrm{~B}$

protein 53

ribosomal protein $\mathrm{S} 6$ kinase beta-1

retinoblastoma-like protein $1, \mathrm{RBL} 1$

catenin delta-1, protein 120

protein 300 (p300-CBP coactivator

family)

phosphorylated adenosine monophosphate

(AMP) activated protein kinase

plasminogen activator inhibitor-1

poly-ADP-ribose polymerase

phosphoenolpyruvate carboxykinase,

PEPCK

cytoplasmic phosphoenolpyruvate

carboxykinase 1, PEPK-C

mitochondrial phosphoenolpyruvate

carboxykinase 1, PEPK-M

precancerous niche

polycystic ovarian syndrome

pathological complete response

programmed cell death protein 1

patient-derived xenograft

proline-, glutamic acid- and leucine-rich

protein-1

phosphoenolpyruvate carboxykinase, PCK

cytoplasmic phosphoenolpyruvate

carboxykinase 1, PCK1

mitochondrial phosphoenolpyruvate

carboxykinase 1, PCK2

progression free survival

prostaglandin G2, (Z)-7-[(1S,4R,5R,6R)-

5-[(E,3S)-3-hydroperoxyoct-1-enyl]-2,3-

dioxabicyclo[2.2.1]heptan-6-yl]hept-5-

enoic acid

prostaglandin E2

prostaglandin H2, (Z)-7-[(1S,4R,5R,6R)-5-

[(E,3S)-3-hydroxyoct-1-enyl]-2,3-

dioxabicyclo[2.2.1] heptan-6-yl]hept-

5 -enoic acid

prostaglandine F2 alpha, (Z)-7-

[(1R,2R,3R,5S)-3,5-dihydroxy-2-[(E,3S)-

3-hydroxyoct-1-enyl]cyclopentyl]hept-

5 -enoic acid

prostaglandin D2, (Z)-7-[(1R,2R,5S)-5-

hydroxy-2-[(E,3S)-3-hydroxyoct-1-enyl]-3-

oxocyclopentyl]hept-5-enoic acid

prostaglandin E2, (Z)-7-[(1R,2R,3R)-3-

hydroxy-2-[(E,3S)-3-hydroxyoct-1-enyl]-5-

oxocyclopentyl]hept-5-enoic acid

phosphatidylinositide 3-kinase

protein kinase $\mathrm{A}$

protein kinase $\mathrm{B}$ (Akt)

pyruvate kinase $\mathrm{M} 2$

phosphatase protein phosphatase $2 \mathrm{~A}$
PPP2R4

Pro-MMP-1

Pro-MMP-7

Pro-MMP-9

pS6K1

PUMA

Rac1

RAG

Rap1

RAPGEF3

Rho

RNA

ROS

S1P

sAC

sICAM-1

Snail

SOD2

SOX

SOX4

SP1

SphK

STAT3

STK11

SVCAM-1

$\mathrm{T} 2 \mathrm{D}$

TGF- $\beta$

TIMP1

$\mathrm{TNF} \alpha$

t-PA

TSC

TSP-1

TXA2

VEGF

vWF

\section{Acknowledgments}

The manuscripts of this Special Issue were supported by the Theodor-Billroth-Academy ${ }^{\circledR}\left(\right.$ TBA $\left.^{\circledR}\right)$ and INCORE (International Consortium of Research Excellence) of the $\left(\mathrm{TBA}^{\circledR}\right)$. We express our gratitude to the discussions on the web group of the Theodor-Billroth-Academy ${ }^{\circledR}$ $\left(\mathrm{TBA}^{\circledR}\right)$ on LinkedIn, the exchange with scientists at serine/threonine-protein phosphatase $2 \mathrm{~A}$ regulatory subunit B'

pro matrix metalloproteinase 7

pro-matrix metalloproteinase 9

knase

Ragulator-Rag complex

Ras-related protein 1, Ras-proximate-1

Rap guanine nucleotide exchange factor 3 , exchange factor directly activated by

cAMP 1, EPAC1

ribonucleic acid

reactive oxygen species

sphingosine-1-phosphate

soluble adenylyl cyclase

zinc finger protein SNAI1

manganese-dependent superoxide

dismutase, MnSOD

[sex-determining region Y (Sry) boxcontaining] transcription factor family

[sex-determining region Y (Sry) box-

containing] transcription factor 4

specificity protein 1

sphingosine kinase isoform

signal transducer and activator of

transcriptor 3

serine/threonine kinase 11, liver kinase B1,

type 2 diabetes

transforming growth factor beta

tissue inhibitor of metalloproteinase 1

tumor necrosis factor alpha

tissue-type plasminogen activator

tuberous sclerosis complex

thrombospondin-1

thromboxane A2, (Z)-7-[(1S,2S,3R,5S)-

3-[(E,3S)-3-hydroxyoct-1-enyl]-4,6-

dioxabicyclo[3.1.1]heptan-2-yl]hept-

5 -enoic acid

vascular endothelial growth factor

von Willebrand factor pro-matrix metalloproteinase 1

\author{
(1)
}


Researchgate.com, as well as personal exchanges with distinguished colleagues who stimulated our thinking all named individually earlier in publications - we thank each one. We further gratefully acknowledge the support of Marjan S. Rupnik, Ph.D., Professor of Physiology, Institute of Physiology, Center for Physiology and Pharmacology, Medical University of Vienna, Austria, for pre-submission review of the literature and our fruitful discussions.

\section{Conflict of interest}

The author reports the following conflict of interest: Björn LDM Brücher is Editor-in-Chief in Life SciencesMedicine of 4open by EDP Sciences. Ijaz S. Jamall is Senior Editorial Board member in Life Sciences-Medicine of 4open by EDP Sciences. The authors, of their own initiative, suggested to the Managing Editorial to perform a transparent peer-review of their submittals. Neither author took any action to influence the standard submission and peer-review process, and report no conflict of interest. The authors alone are responsible for the content and writing of the manuscript of this Special Issue. This manuscript contains original material that has not previously been published. Both authors contributed to the discussion on its contents and approved the manuscript.

\section{References}

1. World Health Organization (2014), "Ageing well" must be a global priority, World Health Organization, Geneva, November 6, 2014, http://www.who.int/mediacentre/ news/releases/2014/lancet-ageing-series/en/.

2. Brücher BLDM (2018), Science belongs to no one - and to everyone. 4open 1, E1, 1-11. https://doi.org/10.1051/fopen/ 2017501.

3. Lorenzo C, Okoloise M, Williams K, Stern MP, Haffner SM; San Antonio Heart Study (2003), The metabolic syndrome as predictor of type 2 diabetes: the San Antonio heart study. Diabetes Care 26, 11, 3153-3159. https://doi.org/ 10.2337/diacare.26.11.3153.

4. Geiss LS, Wang J, Cheng YJ, Thompson TJ, Barker L, Li Y, Albright AL, Gregg EW (2014), Prevalence and incidence trends for diagnosed diabetes among adults aged 20 to 79 years, United States, 1980-2012. JAMA 312, 12, 1218-1226. https://doi.org/10.1001/jama.2014.11494.

5. Ramachandran A, Snehalatha C, Shetty AS, Nanditha A (2012), Trends in prevalence of diabetes in Asian countries. World J Diabetes 3, 6, 110-117. https://doi.org/10.4239/ wjd.v3.i6.110.

6. Webber L, Divajeva D, Marsh T, McPherson K, Brown M, Galea G, Breda J (2014), The future burden of obesityrelated diseases in the 53 WHO European-Region countries and the impact of effective interventions: a modelling study. BMJ Open 4, 7, e004787. https://doi.org/10.1136/bmjopen2014-004787.

7. Memish ZA, El Bcheraoui C, Tuffaha M, Robinson M, Daoud F, Jaber S, Mikhitarian S, Al Saeedi M, AlMazroa MA, Mokdad AH, Al Rabeeah AA (2014), Obesity and associated factors-Kingdom of Saudi Arabia, 2013. Prev
Chronic Dis 11, E174. https://doi.org/10.5888/pcd11. 140236.

8. Ogden CL, Carroll MD, Kit BK, Flegal KM (2014), Prevalence of childhood and adult obesity in the United States, 2011-2012. JAMA 311, 8, 806-814. https://doi.org/ 10.1001/jama.2014.732.

9. Bardenheier BH, Imperatore G, Devlin HM, Kim SY, Cho P, Geiss LS (2014), Trends in pre-pregnancy diabetes among deliveries in 19 U.S. states, 2000-2010. Am J Prev Med 48, 2, 154-161. https://doi.org/10.1016/j.amepre. 2014.08.031.

10. Gregg EW, Zhuo X, Cheng YJ, Albright AL, Narayan KM, Thompson TJ (2014), Trends in lifetime risk and years of life lost due to diabetes in the USA, 1985-2011: a modelling study. Lancet Diabetes Endocrinol 2, 11, 867-874. https://doi.org/10.1016/S2213-8587(14)70161-5.

11. King DE, Mainous AG 3rd, Carnemolla M, Everett CJ (2009), Adherence to healthy lifestyle habits in US adults, 1988-2006. Am J Med 122, 6, 528-534. https://doi.org/ 10.1016/j.amjmed.2008.11.013.

12. Mathers CD, Stevens GA, Boerma T, White RA, Tobias MI (2015), Causes of international increases in older age life expectancy. Lancet 385, 9967, 540-548. https://doi.org/ 10.1016/S0140-6736(14)60569-9.

13. Brücher BLDM, Jamall IS (2019), Microbiome and morbid obesity increase pathogenic stimulus diversity. 4open 2, 11, 1-16. https://doi.org/10.1051/fopen/2018007.

14. Smith U, Gale EA (2010), Cancer and diabetes: are we ready for prime time? Diabetologia 53, 8, 1541-1544. https://doi.org/10.1007/s00125-010-1815-8.

15. Kasper JS, Giovannucci E (2006), A meta-analysis of diabetes mellitus and the risk of prostate cancer. Cancer Epidemiol Biomarker Prev 15, 11, 2056-2062. https://doi. org/10.1158/1055-9965.EPI-06-0410.

16. Giovannucci E, Harlan DM, Archer MC, Bergenstal RM, Gapstur SM, Habel LA, Pollak M, Regensteiner JG, Yee D (2010), Diabetes and cancer: a consensus report. Diabetes Care 33, 7, 1674-1685. https://doi.org/10.2337/dc10-0666.

17. NIH National Institute of Health, National Center for Biotechnology Information: Metform in. Compound Summary for CID 4091, NIH U.S. National Library of Medicine. http://pubchem.ncbi.nlm.nih.gov//compound/4091? from $=$ summary $\#$ section $=$ Top.

18. Libby G, Donnelly LA, Donnan PT, Alessi DR, Morris AD, Evans JM (2009), New users of metformin are at low risk of incident cancer: a cohort study among people with type 2 diabetes. Diabetes Care 32, 9, 1620-1625. https://doi.org/ $10.2337 / \mathrm{dc} 08-2175$.

19. Chaiteerakij R, Yang JD, Harmsen WS (2013), Risk factors for intrahepatic cholangiocarcinoma: association between metformin use and reduced cancer risk. Hepatology 57, 2, 648-655. https://doi.org/10.1002/hep.26092.

20. Velazquez EM, Mendoza S, Hamer T, Sosa F, Glueck CJ (1994), Metformin therapy in polycystic ovary syndrome reduces hyperinsulinemia, insulin resistance, hyperandrogenemia, and systolic blood pressure, while facilitating normal menses and pregnancy. Metabolism 43, 5, 647-654. PMID: 8177055 .

21. Kidson W (1998), Polycystic ovary syndrome: a new direction in treatment. Med J Aust 169, 10, 537-540. PMID: 9861912.

22. Misugi T, Ozaki K, El Beltagy K, Tokuyama O, Honda K, Ishiko O (2006), Insulin-lowering agents inhibit synthesis of testosterone in ovaries of DHEA-induced PCOS rats. Gynecol Obstet Invest 61, 4, 208-215. https://doi.org/ $10.1159 / 000091496$. 
23. U.S. Food and Drug Administration: "Off-Label" and investigational use of marketed drugs, biologics, and medical devices - information sheet, U.S. Department of Health and Human Services. http://www.fda.gov/Regulatory Information/Guidances/ucm126486.htm

24. Mohamed Suhaimi NA, Phyo WM, Yap HY, Choy SHY, Wei X, Choudhury Y, Tan WJ, Tan LAPY, Foo RSY, Tan SHS, Tiang Z, Wong CF, Koh PK, Tan MH (2017), Metformin inhibits cellular proliferation and bioenergetics in colorectal cancer patient-derived xenografts. Mol Cancer Ther 16, 9, 2035-2044. https://doi.org/10.1158/1535-7163. MCT-16-0793.

25. Blandino G, Valerio M, Cioce M, Mori F, Casadei L, Pulito C, Sacconi A, Biagioni F, Cortese G, Galanti S, Manetti C, Citro G, Muti P, Strano S (2012), Metformin elicits anticancer effects through the sequential modulation of DICER and c-MYC. Nat Commun 3, 865. https://doi. org $/ 10.1038 /$ ncomms1859.

26. Ambros V (2001), microRNAs: tiny regulatos with great potential. Cell 107, 7, 823-826. https://doi.org.1016/ S0092-8674(01)00616-X.

27. Shin NR, Lee JC, Lee HY, Kim MS, Whon TW, Lee MS, Bae JW (2014), An increase in the Akkermansia spp. population induced by metformin treatment improves glucose homeostasis in diet-induced obese mice. Gut 63, 5, 727-735. https://doi.org/10.1136/gutjnl-2012-303839.

28. Wang JH, Bose S, Shin NR, Chin YW, Choi YH, Kim H (2018), Pharmaceutical impact of Houttuynia Cordata and Metformin combination on high-fat-diet-induced metabolic disorders: link to intestinal Microbiota and metabolic Endotoxemia. Front Endocrinol (Lausanne) 9, 620. https://doi.org/10.3389/fendo.2018.00620.

29. Elbere I, Kalnina I, Silamikelis I, Konrade I, Zaharenko L, Sekace K, Radovica-Spalvina I, Fridmanis D, Gudra D, Pirags V, Klovins J (2018), Association of metformin administration with gut microbiome dysbiosis in healthy volunteers. PLoS One 13, 9, e0204317. https://doi.org/ 10.1371/journal.pone.0204317.

30. Pyra KA, Saha DC, Reimer RA (2012), Prebiotic fiber increases hepatic acetyl CoA carboxylase phosphorylation and suppresses glucose-dependent insulinotropic polypeptide secretion more effectively when used with metformin in obese rats. J Nutr 142, 2, 213-220. https://doi.org/10.3945/ jn.111.147132.

31. Lee H, Ko G (2014), Effect of metformin on metabolic improvement and gut microbiota. Appl Environ Microbiol 80, 19, 5935-5943. https://doi.org/10.1128/AEM.01357-14.

32. Forslund K, Hildebrand F, Nielsen T, Falony G, Le Chatelier E, Sunagawa S, Prifti E, Vieira-Silva S, Gudmundsdottir V, Pedersen HK, Arumugam M, Kristiansen K, Voigt AY, Vestergaard H, Hercog R, Costea PI, Kultima JR, Li J, Jørgensen T, Levenez F, Dore J; MetaHIT consortium, Nielsen HB, Brunak S, Raes J, Hansen T, Wang J, Ehrlich SD, Bork P, Pedersen O (2015), Disentangling type 2 diabetes and metformin treatment signatures in the human gut microbiota. Nature 528, 7581, 262-266. https://doi.org/10.1038/nature15766.

33. Zhang X, Zhao Y, Xu J, Xue Z, Zhang M, Pang X, Zhang X, Zhao L (2015), Modulation of gut microbiota by berberine and metformin during the treatment of high-fat dietinduced obesity in rats. Sci Rep 5, 14405. https://doi.org/ 10.1038/srep14405.

34. Holmes D (2016), Gut microbiota: antidiabetic drug treat-ment confounds gut dysbiosis associated with type 2 diabetes mellitus. Nat Rev Endocrinol 12, 2, 61. https://doi.org/ 10.1038/nrendo.2015.222.
35. Mardinoglu A, Boren J, Smith U (2016), Confounding effects of metformin on the human gut microbiome in type 2 diabetes. Cell Metab 23, 1, 10-12. https://doi.org/10.1016/ j.cmet.2015.12.012.

36. Pollak M (2017), The effects of metformin on gut microbiota and the immune system as research frontiers. Diabetologia 60 , 9, 1662-1667. https://doi.org/10.1007/s00125-017-4352-x.

37. Wu H, Esteve E, Tremaroli V, Khan MT, Caesar R, Mannerås-Holm L, Ståhlman M, Olsson LM, Serino M, Planas-Fèlix M, Xifra G, Mercader JM, Torrents D, Burcelin R, Ricart W, Perkins R, Fernàndez-Real JM, Bäckhed F (2017), Metformin alters the gut microbiome of individuals with treatment-naive type 2 diabetes, contributing to the therapeutic effects of the drug. Nat Med 23, 7, 850-858. https://doi.org/10.1038/nm.4345.

38. Turnbaugh PJ, Bäckhed F, Fulton L, Gordon JI (2008), Dietinduced obesity is linked to marked but reversible alterations in the mouse distal gut microbiome. Cell Host Microbe 3, 4, 213-223. https://doi.org/10.1016/j.chom.2008.02.015.

39. Caesar R, Tremaroli V, Kovatcheva-Datchary P, Cani PD, Bäckhed F (2015), Crosstalk between gut microbiota and dietary lipids aggravates WAT inflammation through TLR signaling. Cell Metab 22, 4, 658-668. https://doi.org/ 10.1016/j.cmet.2015.07.026.

40. Raza GS, Putaala H, Hibberd AA, Alhoniemi E, Tiihonen K, Mäkelä KA, Herzig KH (2017), Polydextrose changes the gut microbiome and attenuates fasting triglyceride and cholesterol levels in Western diet fed mice. Sci Rep 7, 1, 5294. https://doi.org/10.1038/s41598-017-05259-3.

41. Lang JM, Pan C, Cantor RM, Tang WHW, GarciaGarcia JC, Kurtz I, Hazen SL, Bergeron N, Krauss RM, Lusis AJ (2018), Impact of Individual Traits, Saturated Fat, and Protein Source on the Gut Microbiome. MBio 9, 6, pii: e01604-18. https://doi.org/10.1128/mBio.01604-18.

42. Dávalos A, Goedeke L, Smibert P, Ramírez CM, Warrier NP, Andreo U, Cirera-Salinas D, Rayner K, Suresh U, Pastor-Pareja JC, Esplugues E, Fisher EA, Penalva LO, Moore KJ, Suárez Y, Lai EC, Fernández-Hernando C (2011), miR-33a/b contribute to the regulation of fatty acid metabolism and insulin signaling. Proc Natl Acad Sci USA 108, 22, 9232-9237. https://doi.org/10.1073/pnas. 1102281108 .

43. Herrera-Merchan A, Cerrato C, Luengo G, Dominguez O, Piris MA, Serrano M, Gonzalez S (2010), miR-33-mediated downregulation of p53 controls hematopoietic stem cell selfrenewal. Cell Cycle (Georgetown, Tex.) 9, 16, 3277-3285. https://doi.org/10.4161/cc.9.16.12598.

44. Luo M, Tan X, Mu L, Luo Y, Li R, Deng X, Chen N, Ren M, Li Y, Wang L, Wu J, Wan Q (2017), MiRNA-21 mediates the antiangiogenic activity of metformin through targeting PTEN and SMAD7 expression and PI3 K/AKT pathway. Sci Rep 7, 43427. https://doi.org/10.1038/srep43427.

45. Yoshimatsu Y, Lee YG, Akatsu Y, Taguchi L, Suzuki HI, Cunha SI, Maruyama K, Suzuki Y, Yamazaki T, Katsura A, Oh SP, Zimmers TA, Lee SJ, Pietras K, Koh GY, Miyazono K, Watabe T (2013), Bone morphogenetic protein-9 inhibits lymphatic vessel formation via activin receptor-like kinase 1 during development and cancer progression. Proc Natl Acad Sci USA 110, 47, 18940-18945. https://doi.org/10.1073/pnas.1310479110.

46. Mitchell D, Pobre EG, Mulivor AW, Grinberg AV, Castonguay R, Monnell TE, Solban N, Ucran JA, Pearsall RS, Underwood KW, Seehra J, Kumar R (2010), ALK1-Fc inhibits multiple mediators of angiogenesis and suppresses tumor growth. Mol Cancer Ther 9, 2, 379-388. https://doi. org/10.1158/1535-7163.MCT-09-0650. 
47. Cunha SI, Bocci M, Lövrot J, Eleftheriou N, Roswall P, Cordero E, Lindström L, Bartoschek M, Haller BK, Pearsall RS, Mulivor AW, Kumar R, Larsson C, Bergh J, Pietras K (2015), Endothelial ALK1 Is a therapeutic target to block metastatic dissemination of breast cancer. Cancer Res 75, 12, 2445-2456. https://doi.org/10.1158/ 0008-5472.CAN-14-3706. Erratum. In: Cancer Res. 2016 Oct 15;76(20):6131-6132.

48. Cai X, Hu X, Tan X, Cheng W, Wang Q, Chen X, Guan Y, Chen C, Jing X (2015), Metformin induced AMPK activation, G0/G1 phase cell cycle arrest and the inhibition of growth of esophageal squamous cell carcinomas in vitro and in vivo. PLoS One 10, 7, e0133349. https://doi.org/ 10.1371/journal.pone.0133349.

49. Ying Y, Ueta T, Jiang S, Lin H, Wang Y, Vavvas D, Wen R, Chen YG, Luo Z (2017), Metformin inhibits ALK1mediated angiogenesis via activation of AMPK. Oncotarget 8, 20, 32794-32806. https://doi.org/10.18632/oncotarget. 15825 .

50. Dallaglio K, Bruno A, Cantelmo AR, Esposito AI, Ruggiero L, Orecchioni S, Calleri A, Bertolini F, Pfeffer U, Noonan DM, Albini A (2014), Paradoxic effects of metformin on endothelial cells and angiogenesis. Carcinogenesis 35, 5, 1055-1066. https://doi.org/10.1093/carcin/ bgu001.

51. Kefas BA, Cai Y, Kerckhofs K, Ling Z, Martens G, Heimberg H, Pipeleers D, Van de Casteele M (2004), Metformin-induced stimulation of AMP-activated protein kinase in beta-cells impairs their glucose responsiveness and can lead to apoptosis. Biochem Pharmacol 68, 3, 409-416. PMID: 14678861.

52. Bae EJ, Cho MJ, Kim SG (2007), Metformin prevents an adaptive increase in GSH and induces apoptosis under the conditions of GSH deficiency in H4IIE cells. J Toxicol Environ Health A 70, 15-16, 1371-1380. https://doi.org/ 10.1080/15287390701434430.

53. Alimova IN, Liu B, Fan Z, Edgerton SM, Dillon T, Lind SE, Thor AD (2009), Metformin inhibits breast cancer cell growth, colony formation and induces cell cycle arrest in vitro. Cell Cycle 8, 6, 909-915. https://doi.org/10.4161/ cc.8.6.7933.

54. Ota K, Nakamura J, Li W, Kozakae M, Watarai A, Nakamura N, Yasuda Y, Nakashima E, Naruse K, Watabe K, Kato K, Oiso Y, Hamada Y (2007), Metformin prevents methylglyoxal-induced apoptosis of mouse Schwann cells. Biochem Biophys Res Commun 357, 1, 270-275. https://doi.org/10.1016/j.bbrc.2007.03.140.

55. Wang LW, Li ZS, Zou DW, Jin ZD, Gao J, Xu GM (2008), Metformin induces apoptosis of pancreatic cancer cells. World J Gastroenterol 14, 47, 7192-7198. PMCID: PMC4988356.

56. Lee BB, Kim Y, Kim D, Cho EY, Han J, Kim HK, Shim YM, Kim DH (2019), Metformin and tenovin-6 synergistically induces apoptosis through LKB1-independent SIRT1 down-regulation in non-small cell lung cancer cells. J Cell Mol Med 23, 11. https://doi.org/10.1111/jcmm.14194.

57. Cho SY, Lee HJ, Lee HJ, Jung DB, Kim H, Sohn EJ, Kim B, Jung JH, Kwon BM, Kim SH (2013), Activation of AMP-activated protein kinase $\alpha$ and extracelluar signalregulated kinase mediates CB-PIC-induced apoptosis in hypoxic SW620 colorectal cancer cells. Evid Based Complement Alternat Med 2013, 974313. https://doi.org/ 10.1155/2013/974313.

58. Sena P, Mancini S, Benincasa M, Mariani F, Palumbo C, Roncucci L (2018), Metformin induces apoptosis and alters cellular responses to oxidative stress in Ht29 colon cancer cells: preliminary findings. Int J Mol Sci 19, 5, 1-16. https://doi.org/10.3390/ijms19051478.

59. Wang L, Li K, Lin X, Yao Z, Wang S, Xiong X, Ning Z, Wang J, Xu X, Jiang Y, Liu D, Chen Y, Zhang D, Zhang H (2019 Feb 13), Metformin induces human esophageal carcinoma cell pyroptosis by targeting the miR-497/PELP1 Axis. Cancer Lett 450, 22-31, pii: S0304-3835(19)30086-2. https://doi.org/10.1016/j.canlet.2019.02.014.

60. Tomic T, Botton T, Cerezo M, Robert G, Luciano F, Puissant A, Gounon P, Allegra M, Bertolotto C, Bereder JM, Tartare-Deckert S, Bahadoran P, Auberger P, Ballotti R, Rocchi S (2011), Metformin inhibits melanoma development through autophagy and apoptosis mechanisms. Cell Death Dis 2, e199. https://doi.org/10.1038/cddis.2011.86.

61. Janjetovic K, Vucicevic L, Misirkic M, Vilimanovich U, Tovilovic G, Zogovic N, Nikolic Z, Jovanovic S, Bumbasirevic $\mathrm{V}$, Trajkovic V, Harhaji-Trajkovic L (2011), Metformin reduces cisplatin-mediated apoptotic death of cancer cells through AMPK-independent activation of Akt. Eur J Pharmacol 651, 1-3, 41-50. https://doi.org/10.1016/j. ejphar.2010.11.005.

62. Garofalo C, Capristo M, Manara MC, Mancarella C,

Landuzzi L, Belfiore A, Lollini PL, Picci P, Scotlandi K (2013), Metformin as an adjuvant drug against pediatric sarcomas: hypoxia limits therapeutic effects of the drug. PLoS One 8, 12, e83832. https://doi.org/10.1371/journal. pone.0083832.

63. Gatenby RA, Kessler HB, Rosenblum JS, Coia LR, Moldofsky PJ, Hartz WH, Broder GJ (1988), Oxygen distribution in squamous cell carcinoma metastases and its relationship to outcome of radiation therapy. Int J Radiat Oncol Biol Phys 14, 5, 831-838. PMID: 3360652.

64. Petrova V, Annicchiarico-Petruzzelli M, Melino G, Amelio I (2018), The hypoxic tumour microenvironment. Oncogenesis 7, 1, 10. https://doi.org/10.1038/ s41389-017-0011-9.

65. Queiroz EA, Puukila S, Eichler R, Sampaio SC, Forsyth HL, Lees SJ, Barbosa AM, Dekker RF, Fortes ZB, Khaper N (2014), Metformin induces apoptosis and cell cycle arrest mediated by oxidative stress, AMPK and FOXO3a in MCF-7 breast cancer cells. PLoS One 9, 5, e98207. https://doi. org/10.1371/journal.pone.0098207.

66. Curry J, Johnson J, Tassone P, Vidal MD, Menezes DW, Sprandio J, Mollaee M, Cotzia P, Birbe R, Lin Z, Gill K, Duddy E, Zhan T, Leiby B, Reyzer M, Cognetti D, Luginbuhl A, Tuluc M, Martinez-Outschoorn U (2017), Metformin effects on head and neck squamous carcinoma microenvironment: window of opportunity trial. Laryngoscope 127, 8, 1808-1815. https://doi.org/10.1002/lary.26489.

67. Brücher BLDM, Jamall IS (2019), Chronic inflammation evoked by pathogenic stimulus during carcinogenesis. 4open 2, 8, 1-22. https://doi.org/10.1051/fopen/2018006.

68. Morin-Papunen L, Rautio K, Ruokonen A, Hedberg P, Puukka M, Tapanainen JS (2003), Metformin reduces serum C-reactive protein levels in women with polycystic ovary syndrome. J Clin Endocrinol Metab 88, 10, 4649-4654. https://doi.org/10.1210/jc.2002-021688.

69. Wu B, Li S, Sheng L, Zhu J, Gu L, Shen H, La D, Hambly BD, Bao S, Di W (2012), Metformin inhibits the development and metastasis of ovarian cancer. Oncol Rep 28, 3, 903-908. https://doi.org/10.3892/or.2012.1890.

70. He G, Pedersen SB, Bruun JM, Lihn AS, Richelsen B (2003), Metformin, but not thiazolidinediones, inhibits plasminogen activator inhibitor-1 production in human adipose tissue in vitro. Horm Metab Res 35, 1, 18-23. https://doi.org/10.1055/s-2003-38386. 
71. de Jager J, Kooy A, Schalkwijk C, van der Kolk J, Lehert P, Bets D, Wulffelé MG, Donker AJ, Stehouwer CD (2014), Long-term effects of metformin on endothelial function in type 2 diabetes: a randomized controlled trial. J Intern Med 275, 1, 59-70. https://doi.org/10.1111/joim.12128.

72. Calvert JW, Gundewar S, Jha S, Greer JJ, Bestermann WH, Tian R, Lefer DJ (2008), Acute metformin therapy confers cardioprotection against myocardial infarction via AMPK-eNOS-mediated signaling. Diabetes 57, 3, 696-705. https://doi.org/10.2337/db07-1098.

73. Kitadai Y, Haruma K, Sumii K, Yamamoto S, Ue T, Yokozaki H, Yasui W, Ohmoto Y, Kajiyama G, Fidler IJ, Tahara E (1998), Expression of interleukin-8 correlates with vascularity in human gastric carcinomas. Am J Pathol 152, 1, 93-100. PMCID: PMC1858127.

74. Green AR, Green VL, White MC, Speirs V (1997), Expression of cytokine messenger RNA in normal and neoplastic human breast tissue: identification of interleukin- 8 as a potential regulatory factor in breast tumours. Int J Cancer 72, 6, 937941. PMID: 9378554.

75. Freund A, Chauveau C, Brouillet J-P, Lucas A, Lacroix M, Licznar A, Vignon F, Lazennec G (2003), IL-8 expression and its possible relationship with estrogen-receptor-negative status of breast cancer cells. Oncogene 22, 2, 256-265. https://doi.org/10.1038/sj.onc.1206113.

76. Shi Q, Abbruzzese JL, Huang S, Fidler IJ, Xiong Q, Xie K (1999), Constitutive and inducible interleukin 8 expression by hypoxia and acidosis renders human pancreatic cancer cells more tumorigenic and metastatic. Clin Cancer Res 5, 11, 3711-3721. PMID: 10589791.

77. Seaton A, Scullin P, Maxwell PJ, Wilson C, Pettigrew J, Gallagher R, O'Sullivan JM, Johnston PG, Waugh DJ (2008), Interleukin-8 signaling promotes androgen-independent proliferation of prostate cancer cells via induction of androgen receptor expression and activation. Carcinogenesis 29, 6, 1148-1156. https://doi.org/10.1093/carcin/bgn109.

78. Brew R, Erikson JS, West DC, Kinsella AR, Slavin J, Christmas SE (2000), Interleukin-8 as an autocrine growth factor for human colon carcinoma cells in vitro. Cytokine 12, 1, 78-85. https://doi.org/10.1006/cyto.1999.0518.

79. Ladanyi A (2015), Prognostic and predictive significance of immune cells infiltrating cutaneous melanoma. Pigm Cell Melanoma Res 28, 5, 490-500. https://doi.org/10.1111/ pcmr.12371.

80. Xiao Z, Wu W, Poltoratsky V (2017), Metformin sup-pressed CXCL8 expression and cell migration in HEK293/TLR4 cell line. Mediat Inflamm 2017, 6589423. https:/ doi. org $/ 10.1155 / 2017 / 6589423$.

81. Brücher BLDM, Jamall IS (2019), Precancerous niche (PCN), a product of fibrosis with remodeling by incessant chronic inflammation. 4open 2, 11, 1-21. https://doi.org/ 10.1051/ fopen/2018009.

82. Azmoonfar R, Amini P, Saffar H, Rezapoor S, Motevaseli E, Cheki M, Yahyapour R, Farhood B, Nouruzi F, Khodamoradi

E, Shabeeb D, Eleojo Musa A, Najafi M (2018), Metformin protects against radiation-induced pneu-monitis and fibrosis and attenuates upregulation of dual oxidase genes expression. Adv Pharm Bull 8, 4, 697-704. https://doi.org/10.15171/ apb.2018.078.

83. Mortezaee K, Shabeeb D, Musa AE, Najafi M, Farhood B (2018). Metformin as a radiation modifier; implications to normal tissue protection and tumor sensi-tization. Curr Clin Pharmacol. 14, 1, 41-53. https://doi. org $/ 10.2174 / 1574884713666181025141559$.

84. Al-Hashem F, Al-Humayed S, Amin SN, Kamar SS, Mansy

SS, Hassan S, Abdel-Salam LO, Ellatif MA, Alfaifi M, Haidara MA, Al-Ani B (2018), Metformin inhibits
mTOR-HIF- $1 \alpha$ axis and profibrogenic and inflammatory biomarkers in thioacetamide-induced hepatic tissue alterations. J Cell Physiol 234, 6, 9328-9337. https://doi.org/ $10.1002 /$ jcp. 27616.

85. Tan BK, Adya R, Chen J, Farhatullah S, Heutling D, Mitchell D, Lehnert H, Randeva HS (2009), Metformin decreases angiogenesis via NF-kappaB and Erk1/2/Erk5 pathways by increasing the antiangiogenic thrombospondin-1. Cardiovasc Res 83, 3, 566-574. https://doi. org/10.1093/cvr/cvp131.

86. Peng M, Darko KO, Tao T, Huang Y, Su Q, He C, Yin T, Liu Z, Yang X (2017), Combination of metformin with chemotherapeutic drugs via different molecular mechanisms. Cancer Treat Rev 54, 24-33. https://doi.org/ 10.1016/j.ctrv.2017.01.005.

87. Wang JC, Li GY, Li PP, Sun X, Li WM, Li Y, Lu SY, Liu PJ (2017), Suppression of hypoxia-induced excessive angiogenesis by metformin via elevating tumor blood perfusion. Oncotarget 8, 43, 73892-73904. https://doi.org/10.18632/ oncotarget.18029.

88. Li X, Li J, Wang L, Li A, Qiu Z, Qi LW, Kou J, Liu K, Liu $\mathrm{B}$, Huang $\mathrm{F}$ (2016), The role of metformin and resveratrol in the prevention of hypoxia-inducible factor $1 \alpha$ accumulation and fibrosis in hypoxic adipose tissue. Br J Pharmacol 173, 12, 2001-2015. https://doi.org/10.1111/bph.13493.

89. Ishibashi Y, Matsui T, Takeuchi M, Yamagishi S (2013), Metformin inhibits advanced glycation end products (AGEs)-induced growth and VEGF expression in MCF-7 breast cancer cells by suppressing AGEs receptor expression via AMP-activated protein kinase. Horm Metab Res 45, 5, 387-390. https://doi.org/10.1055/s-0032-1331204.

90. Joe SG, Yoon YH, Choi JA, Koh JY (2015), Antiangiogenic effect of metformin in mouse oxygen-induced retinopathy is mediated by reducing levels of the vascular endothelial growth factor receptor Flk-1. PLoS One 10, 3, e0119708. https://doi.org/10.1371/journal.pone.0119708.

91. Orecchioni S, Reggiani F, Talarico G, Mancuso P, Calleri A, Gregato G, Labanca V, Noonan DM, Dallaglio K, Albini A, Bertolini F (2015), The biguanides metformin and phenformin inhibit angiogenesis, local and metastatic growth of breast cancer by targeting both neoplastic and microenvironment cells. Int J Cancer 136, 6, E534-E544. https://doi. org/10.1002/ijc.29193.

92. Wang J, Li G, Wang Y, Tang S, Sun X, Feng X, Li Y, Bao G, Li P, Mao X, Wang M, Liu P (2015), Suppression of tumor angiogenesis by metformin treatment via a mechanism linked to targeting of HER2/HIF-1 $\alpha / \mathrm{VEGF}$ secretion axis. Oncotarget 6, 42, 44579-44592. https://doi.org/ 10.18632/oncotarget.6373.

93. Cameron AR, Morrison VL, Levin D, Mohan M, Forteath C, Beall C, McNeilly AD, Balfour DJ, Savinko T, Wong AK, Viollet B, Sakamoto K, Fagerholm SC, Foretz M, Lang CC, Rena G (2016), Anti-Inflammatory effects of metformin irrespective of diabetes status. Circ Res 119, 5, 652-665. https://doi.org/10.1161/CIRCRESAHA.116.308445.

94. Bakhashab S, Ahmed FW, Schulten HJ, Bashir A, Karim S, Al-Malki AL, Gari MA, Abuzenadah AM, Chaudhary AG, Alqahtani MH, Lary S, Ahmed F, Weaver JU (2016), Metformin improves the angiogenic potential of human CD34+ cells co-incident with downregulating CXCL10 and TIMP1 gene expression and increasing VEGFA under hyperglycemia and hypoxia within a therapeutic window for myocardial infarction. Cardiovasc Diabetol 15, 27. https://doi.org/10.1186/s12933-016-0344-2.

95. Kopitz C, Gerg M, Bandapalli OR, Ister D, Pennington CJ, Hauser S, Flechsig C, Krell HW, Antolovic D, Brew K, Nagase H, Stangl M, von Weyhern CW, Brücher BLDM, 
Brand K, Coussens LM, Edwards DR, Krüger A (2007), Tissue inhibitor of metalloproteinases- 1 promotes liver metastasis by induction of hepatocyte growth factor signaling. Cancer Res 67, 18, 8615-8623. https://doi.org/ 10.1158/0008-5472.CAN-07-0232.

96. Kim YW, Kim JY, Park YH, Park SY, Won KC, Choi KH, Huh JY, Moon KH (2006), Metformin restores leptin sensitivity in high-fat-fed obese rats with leptin resistance. Diabetes 55, 3, 716-724. https://doi.org/10.2337/diabetes.55.03.06.db05-0917.

97. Lee CK, Choi YJ, Park SY, Kim JY, Won KC, Kim YW (2012), Intracerebroventricular injection of metformin induces anorexia in rats. Diabetes Metab J 36, 4, 293-299. https://doi.org/10.4093/dmj.2012.36.4.293.

98. Spillane S, Bennett K, Sharp L, Barron TI (2013), A cohort study of metformin exposure and survival in patients with stage I-III colorectal cancer. Cancer Epidemiol Biomarker Prev 22, 8, 1364-1373. https://doi.org/10.1158/1055-9965. EPI-13-0347.

99. Kim YD, Park KG, Lee YS, Park YY, Kim DK, Nedumaran B, Jang WG, Cho WJ, Ha J, Lee IK, Lee CH, Choi HS (2008), Metformin inhibits hepatic gluconeogenesis through AMP-activated protein kinase-dependent regulation of the orphan nuclear receptor SHP. Diabetes 57, 2, 306-314. https://doi.org/10.2337/db07-0381.

100. Miller RA, Chu Q, Xie J, Foretz M, Viollet B, Birnbaum MJ (2013), Biguanides suppress hepatic glucagon signalling by decreasing production of cyclic AMP. Nature 494, 7436, 256-260. https://doi.org/10.1038/nature11808.

101. Madiraju AK, Erion DM, Rahimi Y, Zhang XM, Braddock DT, Albright RA, Prigaro BJ, Wood JL, Bhanot S, MacDonald MJ, Jurczak MJ, Camporez JP, Lee HY, Cline GW, Samuel VT, Kibbey RG, Shulman GI (2014), Metformin suppresses gluconeogenesis by inhibiting mitochondrial glycyerophosphate dehydrogenase. Nature 510, 7506, 542-546. https://doi.org/10.1038/nature13270.

102. Mohammed A, Janakiram NB, Brewer M, Ritchie RL, Marya A, Lightfoot S, Steele VE, Rao CV (2013), Antidiabetic drug metformin prevents progression of pancreatic cancer by targeting in part cancer stem cells and mTOR signaling. Transl Oncol 6, 6, 649-659. https://doi.org/ 10.1593 /tlo. 13556

103. Howell JJ, Hellberg K, Turner M, Talbott G, Kolar MJ, Ross DS, Hoxhaj G, Saghatelian A, Shaw RJ, Manning BD (2017), Metformin inhibits hepatic mTORC1 signaling via dose-dependent mechanisms involving AMPK and the TSC complex. Cell Metab 25, 2, 463-471. https://doi.org/ 10.1016/j.cmet.2016.12.009.

104. Memmott RM, Mercado JR, Maier CR, Kawabata S, Fox SD, Dennis PA (2010), Metformin prevents tobacco carcinogen-induced lung tumorigenesis. Cancer Prev Res (Phila) 3, 9, 1066-1076. https://doi.org/10.1158/19406207.CAPR-10-0055.

105. Yoshida S, Hong S, Suzuki T, Nada S, Mannan AM, Wang J, Okada M, Guan KL, Inoki K (2011), Redox regulates mammalian target of rapamycin complex 1 (mTORC1) activity by modulating the TSC1/TSC2-Rheb GTPase pathway. J Biol Chem 286, 37, 32651-32660. https://doi. org $/ 10.1074 /$ jbc.M111.238014.

106. Kalender A, Selvaraj A, Kim SY, Gulati P, Brûlé S, Viollet B, Kemp BE, Bardeesy N, Dennis P, Schlager JJ, Marette A, Kozma SC, Thomas G (2010), Metformin, independent of AMPK, inhibits mTORC1 in a rag GTPasedependent manner. Cell Metab 11, 5, 390-401. https://doi. org/10.1016/j.cmet.2010.03.014.

107. Vazquez-Martin A, Oliveras-Ferraros C, Menendez JA (2009), The antidiabetic drug metformin suppresses HER2
(erbB-2) oncoprotein overexpression via inhibition of the mTOR effector p70S6K1 in human breast carcinoma cells. Cell Cycle 8, 1, 88-96. https://doi.org/10.4161/ cc.8.1.7499.

108. Kasznicki J, Sliwinska A, Drzewoski J (2014), Metformin in cancer prevention and therapy. Ann Transl Med 2, 6, 57. https://doi.org/10.3978/j.issn.2305-5839.2014.06.01.

109. Tong D, Liu Q, Liu G, Xu J, Lan W, Jiang Y, Xiao H, Zhang D, Jiang J (2017), Metformin inhibits castrationinduced EMT in prostate cancer by repressing COX2/ PGE2/STAT3 axis. Cancer Lett 389, 23-32. https://doi. org/10.1016/j.canlet.2016.12.031.

110. Abdelmonsif DA, Sultan AS, El-Hadidy WF, Abdallah DM (2018), Targeting AMPK, mTOR and $\beta$-catenin by combined metformin and aspirin therapy in HCC: an appraisal in Egyptian HCC patients. Mol Diagn Ther 22, 1, 115-127. https://doi.org/10.1007/s40291-017-0307-7.

111. You A, Cao M, Guo Z, Zuo B, Gao J, Zhou H, Li H, Cui Y, Fang F, Zhang W, Song T, Li Q, Zhu X, Yin H, Sun H, Zhang T (2016), Metformin sensitizes sorafenib to inhibit postoperative recurrence and metastasis of hepatocellular carcinoma in orthotopic mouse models. J Hematol Oncol 9, 20. https://doi.org/10.1186/s13045-016-0253-6.

112. Kim JH, Lee KJ, Seo Y, Kwon JH, Yoon JP, Kang JY, Lee HJ, Park SJ, Hong SP, Cheon JH, Kim WH, Il Kim T (2018), Effects of metformin on colorectal cancer stem cells depend on alterations in glutamine metabolism. Sci Rep 8, 1, 409. https://doi.org/10.1038/s41598-017-18762-4. Erratum. In: Sci Rep 8(1), 13111. https://doi.org/10.1038/s41598-01829895-5.

113. Reshef L, Hanson RW, Ballard FJ (1969), Glyceride-glycerol synthesis from pyruvate. Adaptive changes in phosphoenolpyruvate carboxykinase and pyruvate carboxylase in adipose tissue and liver. J Biol Chem 244, 8, 1994-2001.

114. Beale EG, Chrapkiewicz NB, Scoble HA, Metz RJ, Quick DP, Noble RL, Donelson JE, Biemann K, Granner DK (1985), Rat hepatic cytosolic phosphoenolpyruvate carboxykinase (GTP). Structures of the protein, messenger RNA, and gene. J Biol Chem 260, 19, 10748-10760. PMID: 2993287.

115. Mukhopadhyay B, Concar EM, Wolfe RS (2001), A GTPdependent vertebrate-type phosphoenolpyruvate carboxykinase from Mycobacterium smegmatis. J Biol Chem 276, 19, 16137-16145. https://doi.org/10.1074/jbc.M008960200.

116. Yang J, Kalhan SC, Hanson RW (2009), What is the metabolic role of phosphoenolpyruvate carboxykinase? J Biol Chem 284, 40, 27025-27029. https://doi.org/10.1074/ jbc.R109.040543.

117. O'Brien RM, Lucas PC, Forest CD, Magnuson MA, Granner DK (1990), Identification of a sequence in the PEPCK gene that mediates a negative effect of insulin on transcription. Science 249, 4968, 533-537. PMID: 2166335.

118. Montal ED, Dewi R, Bhalla K, Ou L, Hwang BJ, Ropell AE, Gordon C, Liu WJ, DeBerardinis RJ, Sudderth J, Twaddel W, Boros LG, Shroyer KR, Duraisamy S, Drapkin R, Powers RS, Rohde JM, Boxer MB, Wong KK, Girnun GD (2015), PEPCK coordinates the regulation of central carbon metabolism to promote cancer cell growth. Mol Cell 60, 4, 571-583. https://doi.org/10.1016/j.molcel.2015.09.025.

119. Vincent EE, Sergushichev A, Griss T, Gingras MC, Samborska B, Ntimbane T, Coelho PP, Blagih J, Raissi TC, Choinière L, Bridon G, Loginicheva E, Flynn BR, Thomas EC, Tavaré JM, Avizonis D, Pause A, Elder DJ, Artyomov MN, Jones RG (2015), Mitochondrial phosphoenolpyruvate carboxykinase regulates metabolic adaptation and enables glucose-independent tumor growth. Mol Cell 60, 2, 195-207. https://doi.org/10.1016/j.molcel.2015. 08.013 . 
120. Ma R, Zhang W, Tang K, Zhang H, Zhang Y, Li D, Li Y, Xu P, Luo S, Cai W, Ji T, Katirai F, Ye D, Huang B (2013), Switch of glycolysis to gluconeogenesis by dexamethasone for treatment of hepatocarcinoma. Nat Commun 4, 2508. https://doi.org/10.1038/ncomms3508.

121. Liu MX, Jin L, Sun SJ, Liu P, Feng X, Cheng ZL, Liu WR, Guan KL, Shi YH, Yuan HX, Xiong Y (2018), Metabolic reprogramming by PCK1 promotes TCA cataplerosis, oxidative stress and apoptosis in liver cancer cells and suppresses hepatocellular carcinoma. Oncogene 37, 12, 1637-1653. https://doi.org/10.1038/s41388-017-0070-6.

122. Tuo L, Xiang J, Pan X, Hu J, Tang H, Liang L, Xia J, Hu Y, Zhang W, Huang A, Wang K, Tang N (2019), PCK1 negatively regulates cell cycle progression and hepatoma cell proliferation via the AMPK/p27Kip1 axis. J Exp Clin Cancer Res 38, 1, 50. https://doi.org/10.1186/s13046-019-1029-y.

123. Stimson RH, Walker BR (2013), The role and regulation of $11 \beta$-hydroxysteroid dehydrogenase type 1 in obesity and the metabolic syndrome. Horm Mol Biol Clin Investig 15, 2, 37-48. https://doi.org/10.1515/hmbci-2013-0015.

124. Onodera Y, Nam JM, Bissell MJ (2014), Increased sugar uptake promotes oncogenesis via EPAC/RAP1 and O-GlcNAc pathways. J Clin Invest 124, 1, 367-384. https://doi.org/10.1172/JCI63146.

125. Zhou X, Zhang P, Wang Q, Ji N, Xia S, Ding Y, Wang Q (2019), Metformin ameliorates experimental diabetic periodontitis independently of mammalian target of rapamycin (mTOR) inhibition by reducing NIMA-related kinase 7 (Nek7) expression. J Periodontol. [Epub ahead of print]. https://doi.org/10.1002/jper.10311.

126. Brücher BLDM, Jamall IS (2019), Transition from normal to cancerous cell by precancerous niche $(\mathrm{PCN})$ induced chronic cell-matrix stress. 4open 2. https://doi.org/10.1051/fopen/ 2018996.

127. Lee JH, Kim JH, Kim JS, Chang JW, Kim SB, Park JS, Lee SK (2013), AMP-activated protein kinase inhibits TGF- $\beta$-, angiotensin II-, aldosterone-, high glucose-, and albumin-induced epithelial-mesenchymal transition. Am J Physiol Renal Physiol 304, 6, F686-F697. https://doi.org/ 10.1152/ajprenal.00148.2012.

128. Zhang J, Shen C, Wang L, Ma Q, Xia P, Qi M, Yang M, Han B (2014), Metformin inhibits epithelial-mesenchymal transition in prostate cancer cells: involvement of the tumor suppressor miR30a and its target gene SOX4. Biochem Biophys Res Commun 452, 3, 746-752. https://doi.org/ 10.1016/j.bbrc.2014.08.154.

129. Cheng K, Hao M (2016), Metformin inhibits TGF- $\beta 1$ induced epithelial-to-mesenchymal transition via PKM2 relative-mTOR/p70s6 $\mathrm{k}$ signaling pathway in cervical carcinoma cells. Int J Mol Sci 17, 12, 1-14. https://doi. org/10.3390/ijms17122000.

130. Li YG, Han BB, Li F, Yu JW, Dong ZF, Niu GM, Qing YW, Li JB, Wei M, Zhu W (2016), High glucose induces down-regulated GRIM-19 expression to activate STAT3 signaling and promote cell proliferation in cell culture. PLoS One 11, 4, e0153659. https://doi.org/10.1371/journal. pone.0153659.

131. Zhao Z, Cheng X, Wang Y, Han R, Li L, Xiang T, He L, Long H, Zhu B, He Y (2014), Metformin inhibits the IL-6-induced epithelial-mesenchymal transition and lung adenocarcinoma growth and metastasis. PLoS One 9, 4, e95884. https://doi.org/10.1371/journal.pone.0095884.

132. Hirsch HA, Iliopoulos D, Struhl K (2013), Metformin inhibits the inflammatory response associated with cellular transformation and cancer stem cell growth. Proc Natl Acad Sci USA 110, 3, 972-977. https://doi.org/10.1073/pnas. 1221055110.
133. Akinyeke T, Matsumura S, Wang X, Wu Y, Schalfer ED, Saxena A, Yan W, Logan SK, Li X (2013), Metformin targets c-MYC oncogene to prevent prostate cancer. Carcinogenesis $34, \quad 12, \quad 2823-2832$. https://doi.org/ 10.1093/carcin/bgt307.

134. Kawashima I, Kirito K (2016), Metformin inhibits JAK2V617F activity in MPN cells by activating AMPK and PP2A complexes containing the B56 $\alpha$ subunit. Exp Hematol 44, 12, 1156-1165.e4. https://doi.org/10.1016/ j.exphem.2016.08.005.

135. Yang Y, Jin G, Liu H, Liu K, Zhao J, Chen X, Wang D, Bai R, Li X, Jang Y, Lu J, Xing Y, Dong Z (2017), Metformin inhibits esophageal squamous cell carcinoma-induced angiogenesis by suppressing JAK/STAT3 signaling pathway. Oncotarget 8, 43, 74673-74687. https://doi.org/10.18632/ oncotarget.20341.

136. Feng Y, Ke C, Tang Q, Dong H, Zheng X, Lin W, Ke J, Huang J, Yeung SC, Zhang H (2014), Metformin promotes autophagy and apoptosis in esophageal squamous cell carcinoma by downregulating Stat3 signaling. Cell Death Dis 5, e1088. https://doi.org/10.1038/cddis.2014.59.

137. Leonel C, Borin TF, de Carvalho Ferreira L, Moschetta MG, Bajgelman MC, Viloria-Petit AM, de Campos Zuccari DA (2017), Inhibition of epithelial-mesenchymal transition and metastasis by combined TGFbeta knockdown and metformin treatment in a canine mammary cancer Xenograft model. J Mammary Gland Biol Neoplasia 22, 1, 27-41. https://doi.org/10.1007/s10911-016-9370-7.

138. Valaee S, Yaghoobi MM, Shamsara M (2017), Metformin inhibits gastric cancer cells metastatic traits through suppression of epithelial-mesenchymal transition in a glucose-independent manner. PLoS One 12, 3, e0174486. https://doi.org/10.1371/journal.pone.0174486.

139. Trinh SX, Nguyen HT, Saimuang K, Prachayasittikul V, Chan On W (2017), Metformin inhibits migration and invasion of cholangiocarcinoma cells. Asian Pac J Cancer Prev 18, 2, 473-477. https://doi.org/10.22034/ APJCP.2017. 18.2.473.

140. Sun XJ, Zhang P, Li HH, Jiang ZW, Jiang CC, Liu H (2104), Cisplatin combined with metformin inhibits migration and invasion of human nasopharyngeal carcinoma cells by regulating E-cadherin and MMP-9. Asian Pac J Cancer Prev 15, 9, 4019-4023. https://doi.org/10.7314/ APJCP.2014.15.9.4019.

141. ClinicalTrials.gov [Internet], Bethesda, MD, USA (2019 Feb), National Library of Medicine (US), access 2019 Feb 20, https://clinicaltrials.gov/ct2/results? term $=$ cancer\&cond $=$ Metformin .

142. Brücher BLDM, Jamall IS (2019), Eicosanoids in carcinogenesis. 4open 2, 9, 1-34. https://doi.org/10.1051/fopen/ 2018008.

143. Chin-Hsiao T (2019), Metformin and the risk of dementia in type 2 diabetes patients. Aging Dis 10, 1, 37-48. https://doi.org/10.14336/AD.2017.1202.

144. Evans JM, Donnelly LA, Emslie-Smith AM, Alessi DR, Morris AD (2005), Metformin and reduced risk of cancer in diabetic patients. BMJ 330, 7503, 1304-1305. https://doi. org/10.1136/bmj.38415.708634.F7.

145. Bosco JL, Antonsen S, Sørensen HT, Pedersen L, Lash TL (2011), Metformin and incident breast cancer among diabetic women: a population-based case-control study in Denmark. Cancer Epidemiol Biomarkers Prev 20, 1, 101-111. https://doi.org/10.1158/1055-9965.EPI-10-0817.

146. Tseng CH (2014), Metformin significantly reduces incident prostate cancer risk in Taiwanese men with type 2 diabetes mellitus. Eur J Cancer 50, 2831-2837. https://doi.org/ 10.1016/j.ejca.2014.08.007. 
147. Ramos Peñafiel C, Olarte Carrillo I, Ceron Maldonado R, Miranda Peralta E, Rozen Fuller E, Kassack Ipiña JJ, Centeno Cruz F, Collazo Jaloma J, Martínez Tovar A (2018), Effect of metformin added to chemotherapy on the survival of patients with acute lymphoblastic leukemia. Rev Med Chil 146, 7, 846-853. 10.4067/s003498872018000700846.

148. Malik M, Tasnim N, Mahmud G (2018), Effect of metformin alone compared with metformin plus simvastatin on polycystic ovarian syndrome in Pakistani women. J Coll Physicians Surg Pak 28, 3, 184-187. https://doi.org/ 10.29271/jcpsp.2018.03.184.

149. Geagea AG, Rizzo M, Jurjus A, Cappello F, Leone A, Tomasello G, Gracia C, Al Kattar S, Massaad-Massade L, Eid A (2019), A novel therapeutic approach to colorectal cancer in diabetes: role of metformin and rapamycin. Oncotarget 10, 13, 1284-1305. https://doi.org/10.18632/ oncotarget.26641.

150. Martin-Castillo B, Pernas S, Dorca J, Álvarez I, Martínez S, Pérez-Garcia JM, Batista-López N, Rodríguez-Sánchez CA, Amillano K, Domínguez S, Luque M, Stradella A, Morilla I, Viñas G, Cortés J, Cuyàs E, Verdura S, Fernández-Ochoa Á, Fernández-Arroyo S, Segura-Carretero A, Joven J, Pérez E, Bosch N, Garcia M, López-Bonet E, Saidani S, Buxó M, Menendez JA (2018), A phase 2 trial of neoadjuvant metformin in combination with trastuzumab and chemotherapy in women with early HER2-positive breast cancer: the METTEN study. Oncotarget 9, 86, 35687-35704. https://doi.org/10.18632/oncotarget.26286.

151. Davis SR, Robinson PJ, Jane F, White S, Brown KA, Piessens S, Edwards A, McNeilage J, Woinarski J, Chipman M, Bell RJ (2018), The benefits of adding metformin to tamoxifen to protect the endometrium-A randomized placebocontrolled trial. Clin Endocrinol (Oxf) 89, 5, 605-612. https://doi.org/10.1111/cen.13830.

152. Dowling RJ, Niraula S, Chang MC, Done SJ, Ennis M, McCready DR, Leong WL, Escallon JM, Reedijk M, Goodwin PJ, Stambolic V (2015), Changes in insulin receptor signaling underlie neoadjuvant metformin administration in breast cancer: a prospective window of opportunity neoadjuvant study. Breast Cancer Res 17, 32. https://doi.org/10.1186/s13058-015-0540-0.

153. Tanti JF, Grémeaux T, Van Obberghen E, Le MarchandBrustel Y (1991), Effects of okadaic acid, an inhibitor of protein phosphatases-1 and $-2 \mathrm{~A}$, on glucose transport and metabolism in skeletal muscle. J Biol Chem 266, 4, 20992103. PMID: 1846612.

154. Lavoie L, Bollen M, Stalmans W, van de Werve G (1991), Increased synthase phosphatase activity is responsible for the super-activation of glycogen synthase in hepatocytes from fasted obese Zucker rats. Endocrinology 129, 5, 2674-2678.

155. Li X, Scuderi A, Letsou A, Virshup DM (2002), B56associated protein phosphatase $2 \mathrm{~A}$ is required for survival and protects from apoptosis in Drosophila melanogaster. Mol Cell Biol 22, 11, 3674-3684. PMCID: PMC133809.

156. Yu LG, Packman LC, Weldon M, Hamlett J, Rhodes JM (2004), Protein phosphatase 2A, a negative regulator of the ERK signaling pathway, is activated by tyrosine phosphorylation of putative HLA class II-associated protein I (PHAPI)/pp32 in response to the antiproliferative lectin, jacalin. J Biol Chem 279, 40, 41377-41383. https://doi.org/ 10.1074/jbc.M400017200.
157. Messner DJ, Romeo C, Boynton A, Rossie S (2006), Inhibition of PP2A, but not PP5, mediates p53 activation by low levels of okadaic acid in rat liver epithelial cells. J Cell Biochem 99, 1, 241-255. https://doi.org/10.1002/jcb.20919.

158. Van Kanegan MJ, Adams DG, Wadzinski BE, Strack S (2005), Distinct protein phosphatase 2A heterotrimers modulate growth factor signaling to extracellular signal-regulated kinases and Akt. J Biol Chem 280, 43, 36029-36036. https://doi.org/10.1074/jbc.M506986200.

159. Lin JX, Xie XS, Weng XF, Zheng CH, Xie JW, Wang JB, Lu J, Chen QY, Cao LL, Lin M, Tu RH, Huang CM, Li P (2018), The prognostic value of cyclin-dependent kinase 5 and protein phosphatase $2 \mathrm{~A}$ in gastric cancer. J Cancer 9, 23, 4404-4412. https://doi.org/10.7150/jca.27015.

160. Ho WS, Wang H, Maggio D, Kovach JS, Zhang Q, Song Q, Marincola FM, Heiss JD, Gilbert MR, Lu R, Zhuang Z (2018), Pharmacologic inhibition of protein phosphatase-2A achieves durable immune-mediated antitumor activity when combined with PD-1 blockade. Nat Commun 9, 1, 2126. https://doi.org/10.1038/s41467-018-04425-z.

161. Hanawa S, Mitsuhashi A, Shozu M (2018), Antitumor effects of metformin via indirect inhibition of protein phosphatase $2 \mathrm{~A}$ in patients with endometrial cancer. PLoS One 13, 2, e0192759. https://doi.org/10.1371/journal. pone.0192759.

162. Marrone KA, Zhou X, Forde PM, Purtell M, Brahmer JR, Hann CL, Kelly RJ, Coleman B, Gabrielson E, Rosner GL, Ettinger DS (2018), A randomized phase II study of metformin plus paclitaxel/carboplatin/bevacizumab in patients with chemotherapy-naïve advanced or metastatic nonsquamous non-small cell lung cancer. Oncologist 23, 7, 859-865. https://doi.org/10.1634/theoncologist.2017-0465.

163. Moro M, Caiola E, Ganzinelli M, Zulato E, Rulli E, Marabese M, Centonze G, Busico A, Pastorino U, de Braud FG, Vernieri C, Simbolo M, Bria E, Scarpa A, Indraccolo S, Broggini M, Sozzi G, Garassino MC (2018), Metformin enhances cisplatin-induced apoptosis and prevents resistance to cisplatin in co-mutated KRAS/LKB1 NSCLC. J Thorac Oncol 13, 11, 1692-1704. https://doi.org/10.1016/j. jtho.2018.07.102.

164. Richards KA, Liou JI, Cryns VL, Downs TM, Abel EJ, Jarrard DF (2018), Metformin use is associated with improved survival for patients with advanced prostate cancer on androgen deprivation therapy. J Urol 200, 6, 1256-1263, pii: S0022-5347(18)43412-X. https://doi.org/ 10.1016/j.juro.2018.06.031.

165. Curry JM, Johnson J, Mollaee M, Tassone P, Amin D, Knops A, Whitaker-Menezes D, Mahoney MG, South A, Rodeck U, Zhan T, Harshyne L, Philp N, Luginbuhl A, Cognetti D, Tuluc M, Martinez-Outschoorn U (2018), Metformin clinical trial in HPV + and HPV - head and neck squamous cell carcinoma: impact on cancer cell apoptosis and immune infiltrate. Front Oncol 8, 436. https://doi.org/10.3389/fonc.2018.00436.

166. Chak A, Buttar NS, Foster NR, Seisler DK, Marcon NE, Schoen R, Cruz-Correa MR, Falk GW, Sharma P, Hur C, Katzka DA, Rodriguez LM, Richmond E, Sharma AN, Smyrk TC, Mandrekar SJ, Limburg PJ; Cancer Prevention Network (2015), Metformin does not reduce markers of cell proliferation in esophageal tissues of patients with Barrett's esophagus. Clin Gastroenterol Hepatol 13, 4, 665-672.e1-4. https://doi.org/10.1016/j.cgh.2014.08.040. 